Revista de Derecho de la Pontificia Universidad Católica de Valparaíso 52 (primer semestre de 2019)

[pp. 153 - 194]

\title{
CAN BRINGING CHILDREN INTO THE WORLD EVER BE REGARDED AS CONTRARY TO THEIR INTERESTS? INTERPRETATION OF SOSTITUTION OR GLOBAL MOTHER'S SURROGACY BETWEEN INTERNATIONAL AND EUROPEAN UNION LAW
}

[¿Puede considerarse que traer niños al mundo es contrario a sus intereses? Interpretación de la sustentación o la subrogación global de la madre entre el derecho internacional y el de la Unión Europea]

\section{DiMITRIS LIAKOPOULOS*}

RESUMEN

El presente trabajo se concentra en el análisis de la subrogación "global" de acuerdo con las normas internacionales y europeas. El proceso interpretativo que hemos seguido nos permite pensar que muchos valores, principios, etc., tanto a nivel internacional, comunitario como nacional, pueden ser contrarrestados y, a menudo, se basan en doctrinas especializadas: temores de contaminación y, en última instancia, de fragmentación de sistemas nacionales de conflicto. En prassi, el derecho internacional privado y el estatus familiar en particular, no son ontológicamente diferentes de cualquier otro campo del derecho interno que experimente las inevitables transformaciones debidas a la apertura a valores normativos $\mathrm{y}$ desarrollos sociales internacionales y europeos que, les guste o no. Están determinados por el futuro de la subrogación como fenómeno global.

\section{Palabras Clave}

Derecho Internacional de Familia subrogación global - protección de los derechos humanos - interés superior del niño - Derecho internacional privado Derecho de la Unión Europea - orden público.

ReCibido el 21 de octubre de 2018 y Aprobado el 3 de junio de 2019.

* Full Professor of European Union Law at the Fletcher School-Tufts University (MA in international law and MA of Arts in Law and diplomacy). Full Professor of International and European Criminal and Procedural Law at the De Haagse Hogenschool-The Hague. Attorney at Law a New York and Bruxelles. ORCID ID: 0000-0002-1048-6468.
The present work is concentrated on the analysis of "global" surrogacy according to international and european rules. The interpretative process that we have followed allows us to think that many values, principles, and so on both at the international, community and national levels can be countered-and often are by specialist doctrine-fears of contamination and, ultimately, of fragmentation of national conflict systems. In prassi, private international law and the family status in particular, are not ontologically different from any other field of domestic law that undergoes the inevitable transformations due to the opening to international and european normative values and social developments that, whether they like it or not, they are determined for the future of subrogation as a global phenomenon.

\section{KEYWORD}

International Family Law - global surrogacy - protection of human rights - best interest of child - international private Law - European Union Law public order - family Law. 


\section{INTRODUCTION}

The phenomenon of surrogate motherhood arises within the controversial issue of medically assisted procreation whose techniques are also used to realize the various hypotheses of maternal subrogation, socalled gestational ${ }^{1}$. We speak of surrogate motherhood when a woman, under payment or for free, makes available her uterus for a couple who can not have children because of the physical impossibility of the woman of the couple herself to carry out a pregnancy, and who commits himself to be artificially fertilized ${ }^{2}$ with the seed of the man of the couple or of an external donor ${ }^{3}$ to it, to complete the pregnancy and finally to hand over the child so conceived to the clients. The surrogate motherhood must be distinguished from the rent of the uterus ${ }^{4}$, another practice often

${ }^{1}$ Fronek, Patricia - Crawshaw, Marilyn, The "new family" as an emerging norm: A commentary on the position of social work in assisted reproduction, en British Journal of Social Work 44 (2014), 2. DAVIS, Erica, The rise of gestational surrogacy and the pressing need for international regulation, en Minnesota Journal of International Law 21 (2012), pp. 122 ss ("describing other forms of unavailability regarding particular procedures or processes, namely sex selection and binding contractual surrogacy agreements [...] forum shopping has also been facilitated by the differences among jurisdictions' legal and policy approaches to surrogacy [...]"). BRUGGER, Kristiana, International law in the gestational surrogacy debate, en Fordham International Law Journal 35 (2012), pp. 668 ss (discussing the risk of exploitation and continuation of gender hierarchies proliferated by the international commercial surrogacy industry). Herman, Amanda, The regulation of gestation: A call for more complete State Statutory Regulation of Gestational Surrogacy Contracts, en Chapman Law Review 18 (2015), pp. 556 ss. SUTER, Sonia, Giving in to baby markets: Regulation without probibition, en Michigan Journal of Gender \& Law 16 (2009), pp. 218 ss (“... we potentially do harm to ourselves and to human flourishing if we treat something integral to ourselves as a commodity, that is, as separate and fungible [...]"). NeLSON, Erin, Global trade and assisted reproductive technologies: Regulatory challenges in international surrogacy, en The Journal of Law, Medicine and Ethics 41 (2013), 1, pp. 242 ss. WADE, Katherine, The regulation of surrogacy: A children's rights perspective, en Child Family Law 29 (2017), 2, pp. 115 ss. MonÉGER, Françoise, Gestation pour autrui: Surrogate motherhood (Paris, Société de Législation Comparée, 2011). SuCKER, Stefanie, To recognize or not to recognize? That is the question!, en European Journal of Law Reform 17 (2015), 2, pp. 258 ss.

${ }^{2}$ Müll-Götzmann, Christian, Artifizielle Reproduktion und gleichgeschlechtliche Elternschaft (Heidelberg, Springer, 2009), pp. 236 ss.

${ }^{3}$ CLARK, Brigitte, $A$ balancing act? The rights of donor-conceived children to know their biological origins, en Georgia Journal of International and Comparative Law 30 (2012), 3, pp. 620 ss. S. GOLOMBOK, Families created by reproductive donation, (2013) 7 in Child Development Perspectives, 7, 2013, pp. 62ss.

${ }^{4}$ Mortazavi, Susan, It takes a village to make a child: Creating guidelines for 
assimilated or confused with the first but which, in reality, represents a completely different type of carrying out the pregnancy on behalf of others. Instead, with the rent of the uterus, in fact, reference is made to the practice with which the woman "commissioned" by the couple is limited to carrying on the pregnancy with the use of genetic material ${ }^{5}$ that is entirely coming from the same clients or possibly from other donors ${ }^{6}$.

The national regulatory choices at the world level are increasingly destined to confront the respect of the fundamental rights of individuals as defined by sources and jurisdictions outside the forum. This leads in some cases to delicate problems of harmonization between internal and international norms (and underlying values) ${ }^{7}$.

international surrogacy, en Georgetown Law Journal 101 (2012), pp. 2272 ss.

${ }^{5}$ Pennings, Guido - Vayena, Efy - Ahuja, Kamal, Balancing ethical criteria for the recruitment of gamete donors, in Richards, M. - Pennings, G. - ApplebY, J., Reproductive donation: Practice, policy and bioethics (Cambridge, Cambridge University Press, 2012), pp. 154 ss.

${ }^{6}$ De Verda y Beamonte, José Ramón, Reprodución humana asistida, en Revista Boliviana de Derecho 7 (2009), pp. 207 ss.

${ }^{7}$ See in argument from the Court of Justice of the European Union (CJEU) the next cases which employed the term "commissioning mother" instead of "intended mother": C-167712, C.D. v. S.T. of 18 March 2014, ECLI:EUC:2014:169, in electronic Reports of cases; C-402/05 P and C-4015/05 P, joined cases, Yassar Abdulla Kadi \& Al Bakaraat International Foundation \& Council of the European Union and European Commission, of 3 September 2008, ECLI:E:C:2008:461, ECR I-06351; C-363/12, Z. v. A Government Department and the Board of Management of a Community School of 18 March 2014, ECLI:EUC:2014:159, in electronic Reports of cases. The Advocate General Nils Wahl distinguished the case: “(...) the situation of a pregnant worker falling under the scope of the Pregnant Workers Directive which provides for maternity leave of at least 14 weeks in order for a woman to recover from childbirth and take care (...) to equate her situation with that of either a woman who has given birth, or an adoptive mother (...)"; C-167/12, C.D. v. S.T of 18 March 2014, ECLI:EU:C:2014:169, in electronic Reports of cases. The Advocate General Kokott said that: “(...) an intended mother who has a baby through a surrogacy arrangement has the right to receive maternity leave provided for under EU law (...) that maternity leave which the surrogate mother has taken must be deducted from the leave of the intended mother. In any case, the leave of the intended mother must amount to at least two weeks. Both the surrogate mother and the intended mother must be given at least two weeks of paid leave each, Kokott said. The remaining 10 weeks of the EU's required 14 must be shared between the two, taking into account the protection of "the woman who has recently given birth and the child's best interests (...). In these case not the intended mother, but the surrogate mother gave birth to the child. Legislation on surrogacy varies greatly in the member states of the EU. In some member states, surrogacy is legally regulated (for example in Austria, Finland and Sweden). The CJEU interpreted both Directives 92/85 and 2006/54 in the C.D. and Z. cases. The question whether the prohibition of discrimination on 
The filiation obtained in third countries by procreation on behalf of others or, according to a common terminology, substitution or subrogation of maternity, is a crucial field of analysis. The examination of these cases shows that external sources influence the way of being of the internal legal system and, in particular, of the system of private international law $^{8}$ which is forged as a protective function of human

the ground of disability was infringed (Directive 2000/78, the so-called Framework Directive). The Court considered that "first, it is legitimate to ensure the protection of a woman's biological condition during pregnancy and thereafter until such time as her physiological and mental functions have returned to normal after childbirth; secondly, it is legitimate to protect the special relationship between a woman and her child over the period which follows pregnancy and childbirth, by preventing that relationship from being disturbed by the multiple burdens which would result from the simultaneous pursuit of employment (...)". Cousins, Mel, Surrogacy leave and EU law, en Maastricht Journal of European and Comparative Law 21 (2014), 2, pp. 478 ss. The Advocate General Kokott stresses the need of protection and the caring role of (commissioning) mothers: “(...) such an approach might imply that rights of fathers are denied (...) underlined once more the especially vulnerable situation of pregnant workers and workers who have recently given birth (...)". See also in argument: CARACCIOLO Di TORELla, Eugenia, Brave new fathers for a brave new world? Fathers as caregivers in an evolving European Union, en European Law Journal 20 (2014), 1, pp. 90 ss. Diovek, Alison - Peleg, Noam - Reece, Helen, Law in society: Reflections on children, family, culture and philosophy. Essays in honour of Michael Freeman (Leiden, Boston, Brill/Nijhoff, 2015, pp. 567 ss. LewIs, Browne, Due date: Enforcing surrogacy promises in the best interest of the child, en St. John's Law Review 87 (2015), 4.

${ }^{8}$ Fentn-Glynn, Claire, Human rights and private international law: Regulating international surrogacy, in Journal of Private International Law 10 (2014), 1, pp. 160 ss. BÜChler, Andrea - Marana, Luca, Surrogacy and international private law in Switzerland, en International Survey Family Law 327 (2015), pp. 4 ss. RotaBI, Karen - Fouten Brufield, Nicole - FroneK, Patricia, International private law to regulate commercial global surrogacy practices. Just about are social work's practical policy recommendations?, en International Social Work 58 (2015). ToBIN, John, To prohibit or permit: what is the (human) rights response to the practice of international commercial surrogacy?, en International Comparative Law Quarterly 63 (2014), pp. 319 ss. STORRow, Richard, The phantom children of the republic: International surrogacy and the new illegitimacy, en American University Journal of Genfer Society Policy \& Law 20 (2012), pp. 563 ss: “... Canada, the Czech Republic, Ireland, and the Netherlands, commercial surrogacy is prohibited through either express criminal law provisions or general criminal law provisions (...) such as those relating to child trafficking (...)". In the Netherlands, although there is no specific legal regulation of noncommercial surrogacy, commercial surrogacy is prohibited by certain provisions of the Criminal Code that: "... criminalize the commission of certain acts committed as part of a commercial surrogacy arrangement (...) the Dutch legislatures objective to fight against commercial surrogacy resulted in the introduction in 1993 of article 151(b) to the Dutch Criminal Code (...)". 
rights ${ }^{9}$. Having separated gestation of the fetus and biological parenting, medical science has created life-generation factors sometimes unknown to national legal systems and where classic bi-parenting leaves room for multiple or potentially such parenting. The recognition of family norms or status acquired abroad re-reveals a particular relationship of contiguity and continuity with the ethical principles of the forum, possesses natural defenses to prevent the entry of extraneous values that are irreconcilable with them ${ }^{10}$. In the face of evolutionary processes tending to interfere with internal ethical principles-theoretically susceptible to reductio ad unum through an international agreement ${ }^{11}$-fears of contamination of the national legal system ${ }^{12}$ arise. The jurisprudence above all at global level has tried to confirm an interpretative approach already envisaged, rectius oriented elsewhere: in the international law of the family and the status of the filii in particular, the questions between principles and underlying ethical requirements can be grouped according to a point de repere constituted from the superior interest of the child, concretely considered in the individual cases. Further evidence is the purpose of the jurisprudence of the European Court of Human Rights (ECtHR) regarding recognition in the forum of status filii ${ }^{13}$ legally perfected abroad in cases of surrogate maternity ${ }^{14}$.

Such legal uncertainty may afflict all those involved: the child (which notably include nationality and statelessness issues, migration issues and legal parentage issues), the intended parents (regarding their status as parents, since it may be far from certain that they will be treated as the legal parents in their country of origin) and the surrogate mother (can she, for example, change her mind and "keep the child" after the child is born?

9 BARATTA, Roberto, La reconnaissance internationale des situations juridiques personnelles et familiales, en Recueil des cours de l'Académie de Droit International de la Haye (Leiden, Brill, 2010), pp. 254 ss.

10 MAYER, Claudia, Verfahrensrechtliche Anerkennung einer ausländischen Abstammungsentscheidung zugunsten eingetragener Lebenspartner im Fall der Leihmutterschaft, en Das Standesamt (2015), pp. 34 ss.

${ }^{11}$ BRUgGer, cit. (n. 1), pp. 668 ss.

${ }^{12}$ Van Gerven, Walter, Harmonization of private law: Do we need it?, en Common Market Law Review 41 (2004), pp. 505ss. Puppinck, Gregor - De la Hougue, Claire, Quelles voies de droit international pour interdire la maternité de substituion (Strasbourg, 2015).

${ }^{13}$ The Convention on Jurisdiction, Applicable law, Recognition, Enforcement and Co-operation in respect of Parental Responsibility and Measures for the Protection of Children, 19th October 1996.

${ }^{14}$ Trimmings, Katarina - PBeaumont, Paul, International surrogacy arrangements: An urgent need for legal regulation at the international level, en Journal of Private International Law 14 (2011), 3, pp. 628 ss. 
What sort of financial compensation or remuneration would be appropriate and how can this sum be claimed within and beyond her own jurisdiction if disputed by the commissioning parents?

\section{THE NEGATIVE APPLICATION OF SOME EUROPEAN LEGISLATION REGARDING PROCREATION ON BEHALF OF OTHERS}

The existence of a plurality of factually or potentially parenting figures causes numerous critical issues. And many European countries are certainly not isolated in countering motherhood by subrogation. In many European countries it is prohibited and sometimes penalized (France ${ }^{15}$, Switzerland ${ }^{16}$, Spain ${ }^{17}$ ). In others it is in principle authorized if it is compatible with certain predetermined conditions ${ }^{18}$ from the law and substantially satisfying the need for subrogation to pursue an altruistic and non-commercial purpose $\left(\mathrm{Olanda}^{19}\right.$ and the United Kingdom $\left.{ }^{20}\right)$. In other states it is tolerated

15 Planchard, Christophe, Vers un renforcement en France du statut juridique de l'enfant issu d'une GPA effectuée à l'étranger, en La Revue des Droits de l'Homme 7 (2015).

${ }^{16}$ Hague Conference on Private International Law, A Preliminary Report on the Issues Arising from International Surrogacy, No. 10 of March 2012, p. 4.

${ }^{17}$ Ley sobre Técnicas de Reproducción Humana Asistida of 2006, 14 May 2006.

${ }^{18}$ Hausammann, Christina - Hitz Quenon, Nicole, Maternité de substitution: La perspective des droits humains, en Centre suisse de compétence pour les droits humains (Newsletter CSDH du 11 mai 2014) pp. 2 ss.

${ }^{19}$ Ex parte MS 2014 JDR 0102 case n. 48856/2010 (GMP) surrogate motherhood agreements and best interests of child. DeRMOUT, Sylvia et al, Non-commercial surrogacy: An account of patient management in the first Dutch Centre for IVF Surrogacy from 1997 to 2004, in Human Reproduction 25 (2010), pp. 448 ss.

${ }^{20}$ See the section 54 dello Human Fertilisation and Embryology Act 2008. In argument also: MARGALIT, Yehezkel, In defense of surrogacy agreements: A modern contract law perceptive, en William \& Mary Journal of Women and the Law 21 (2014), pp. 423ss. 
$\left(\right.$ Belgium $^{21}$, Poland ${ }^{22}$, Thailand ${ }^{23}$, New Zealand ${ }^{24}$, Portugal ${ }^{25}$, United States ${ }^{26}$

${ }^{21}$ According to the Doc. Leg. n. 4-633/1. BuRDI, S., The case of surrogacy leave, en European Journal of Law Reform 17 (2015), 2, pp. 274 ss.

${ }^{22}$ Article 619 of Family and Custody Code stipulates that: “(...) the mother of a child is the biological mother who gave birth". The statute thus requires that the childbearing person is to be indicated as the mother in the birth certificate. Therefore, the Polish law does not make any special provision for the nationality of children born in the context of a surrogacy arrangement. Families legally constituted abroad thanks to surrogacy where parents are of the same sex (both men) and at least one parent is a Polish national encounter problems with confirming Polish nationality of their children in a procedure before a Voivod.Article 8.3 of Act on Polish Citizenship of 1962, Journal of Law 2000, 28, 353 (consolidated version) (Ustawa o obywatelstwie polskim z 12 lutego 1962 r, Dz.U.2000, nr 28, poz. 353 j.t.). See also the judgement of the Supreme Administrative Court of 21 April 2011, case no II OSK 591/10.

${ }^{23}$ Protection for Children Born From Assisted Reproductive Technologies Act, B.E. 2558 (2015).

${ }^{24}$ Status of Children Act 1969 and Children and Family Relationships Bill 2014 (Ireland).Human Assisted Reproductive Technology Act 2004.

25 I.2.After ART regulation (Law n.32/2006). In 2006, Law n.32/2006 (Law n.32/2006, from 26 July, on Medically Assisted Reproduction) was enacted to regulate ART and it expressly banned surrogacy arrangements. Article 14/6, which expressly refers to surrogacy proceedings, stating that: “(...) the beneficiaries and the surrogate mother should be informed in writing about the significance of the surrogate's influence on embryo and foetal development'. This last Article shows that the law distinguishes these two types of participants and does not consider the surrogate to be one of the "beneficiaries of the techniques". Ascensão JO. A Lei n. ${ }^{\circ} 32 / 06$, sobre procriação medicamente assistida. Revista da Ordem dos Advogados. 2007; 67III and the Decreto Regulamentar n. 6/2017 of 31 July 2017. See, RAPOSO, Vera, The new portuguese law on surrogacy: The story of how a promising law does not really regulate surrogacy arrangements, en JBRA Assisted Reproduction 21 (2017), 3, pp. 234 ss. STEHR, Emily, International surrogacy contract regulation: national governments' and international bodies' misguided quests to prevent exploitation, en Hastings International Comparative Law Review 35 (2012), pp. 256 ss.

${ }^{26}$ As we can conclude from the next leading cases: U.S. In re Baby M, 537 A.2d 1227 (N.J. 1988); Roe v Wade, 410 US 113 (1973); Stiver v Parker, 975 F.2d 261 (6th cir. 1992); Turpin v Sortini, (31 Cal 3d 220; 643 P 2d 954 (Cal 1982). See in argument: Gruenbaum, Daniel, Foreign surrogate motherhood: Mater semper certa erat, en American Journal of Comparative Law 60 (2012), pp. 478 ss. The Uniform Parentage Act ("UPA") proposed one solution to the lack of uniformity of U.S. surrogacy laws. The UPA would resolve issues of legal parentage by requiring the intended parents receive a court order stating that they are the legal parents of the resulting children as stated in the surrogacy contract for the agreement PATTON, to be held enforceable, Unifrom Parentage Act par. 803(a) (amended 2002), 9B U.L.A. 90 (Supp. 2015). See also Brock, Buying a newborn: Globalization and the lack of federal regulation of commercial surrogacy contracts, en University of Missouri-Kansas City Law Review 79 (2010), pp. 510 ss. (discussing requirements of surrogacy contracts under the Uniform Parentage Act). LAUFER-UKELES, Pamela, The lost children: When the rights to children conflicts with the rights of children, 
and Great Britain $^{27}$ ) and/or with strict restrictions (Israel ${ }^{28}$, United Kingdom ${ }^{29}$, Greece $^{30}$, India ${ }^{31}$, Canada ${ }^{32}$ ). In others it is commercially exploited by specialized

en Law \& Ethics Human Rights 8 (2014), pp. 220, 262 ss. (recalling a conflict of law case in which British intended parents were denied parental status of a child born to a Ukrainian surrogate, rendering the child effectively stateless and stranded).

27 See the section 54 dello Human Fertilisation and Embryology Act 2008 and its application in the next cases in the matter of surrogacy: D and L (Surrogacy) [2012] [2012] EWHC 2631 (Fam); IJ (A Child) [2011] EWHC 921; J v G [2013] EWHC 1432 (Fam); L (A Minor) [2010] EWHC 3146; Re A \& B (Parental Order Domicile) [2013] EWHC 426 (Fam); Re C (A Child) [2013] EWHC 2413 (Fam); Re K (Minors) (Foreign Surrogacy) [2010] EWHC 1180.Re P-M [2013] EWHC 2328 (Fam); Re W [2013] EWHC 3570 (Fam); Re X and Y (Children) [2011] EWHC 3147 (Fam); X \& Y (Foreign Surrogacy) [2008]; Z and Anor v C [2011] EWHC 3181 (Fam). Braveman, Andrea et. al, Reproduction through surrogacy in the U.K. and U.S.A, en Richards, M. - Penings, G. - Appleby, J., Reproductive donation: Practice, policy and bioethics (Cambridge, Cambridge University Press, 2012), pp. 152 ss. JACKSON, Emily, UK law and international commercial surrogacy: "The very antithesis of sensible", en Journal of Medical Law and Ethics 4 (2016), 3, pp. 198 ss. SCOTT, Rosamund, Reconsidering "wrongful life" in England after thirty years: legislative mistakes and unjustifiable anomalies, en Cambridge Law Journal 72 (2013), 1, pp. 118 ss. GAmBLE, Natalie, A better framework for United Kingdom surrogacy?, en Goloмвок, S. et. al (ed.), Regulating reproductive donation (Cambridge, Cambridge University Press, 2016), pp. 154 ss.

${ }^{28}$ Israel is an example of a country that expressly permits and regulates surrogacy. Surrogacy is regulated in Israel under the Embryo Carrying Agreement Act (Agreement Authorization \& Status of the Newborn Child), 5756-1996. See in argument: Pol, Rutua, Proposing an international instrument to address issues arising out of international surrogacy arrangements, en Georgetown Journal of International Law 48 (2017), pp. 1315 ss.

${ }^{29}$ In Israel and in the U.K., where there are very restrictive domestic regulations, few if any disputes arise around surrogacy arrangements. This stands in stark contrast to the prevailing deregulation in the United States, which manifests itself in bitter legal disputes. Indeed, perhaps the most well known American surrogacy case of baby $\mathrm{M}$ involved a clinic which knew that the surrogate mother, Miss. Whitehead, "demonstrated certain traits that might make surrender of the child difficult," but preferred not to reveal this crucial fact to the intending parents, who eventually sued the clinic. See in argument: LifSHiTz, Shahar, Neither nature nor contract: Toward an institutional perspective on parenthood essay, en Legal \& Ethics Human Rights 8 (2014), pp. 298 ss.

${ }^{30}$ Greek civil code art. 1458, art. 8 of the law 3089/2002 and the Reg. of surrogacy with the law 3305/2009 (enforcement of medically assisted reproduction). RoKas, K. A., Greece, in Trimmings - Pbeaumont, cit. (n. 14), “(...) whether a prohibition is de facto possible remains to be seen, because the State's margin of appreciation in this matter will continuously be weighed against the rights of the individual, and the Court has yet have deemed the State to have stayed within the afforded margin in declining to give legal acknowledgement to filial relationships stemming from surrogacy (...) speculated to have been due to the fact that before Paradiso and Campanelli, at least one of the applicants' had been biologically related to the child, but the latest judgement proved that assumption to have been inaccurate (...)". In the same spirit as we can see precedent in the case from the same court in D. And others v. Belgium of 8 July 2014. Brems, Eva - Desmet, Ellen - Wandenhole, Wouter, Children's rights law in the global human rights landscape (London \& New York, Routledge, 2017).

${ }^{31}$ The Surrogacy (Regulation) Bill, 2016 (Bill No. 257 of 2016).

${ }^{32}$ As we can see form the next cases: Re Children's Aid Society for the District of Kenora 
companies that provide profit-making intermediation activities between the interested parties (Georgia ${ }^{33}$, Norway ${ }^{34}$, Russia ${ }^{35}$, Ukraine ${ }^{36}$, South Afric $^{37}$ ) and others allowed with the means of breeding (Thailand) ${ }^{38}$. Finally, it is worth mentioning that surrogate motherhood is authorized in various North American States ${ }^{39}$ where, at times, it is also the subject

and JL, 134 DLR (3d) 249, 1982 WDFL 390 (Ont Prov Ct); M(J) v. Superintendent of Family and Child Services [1983] 4 CNLR 41, (1983) 35 RFL (2d) 364 (BCCA); Winnipeg Child and Family Services (Northwest Area) v. G (D.F.) (Canadian Supreme Court).

33 Article 143 of the Law of Georgia "On Health"; Article 143 of the Law of Georgia "On Health"Order No.18 of the Minister of Justice of Georgia "On Approval of the Rule of Civil Acts Registration", dated January 31, 2012; Joint Order No.133-No.144 of the Minister of Justice of Georgia and the Minister of Internal Affairs of Georgia "On approval of the rule of exist of a child born as a result of in vitro fertilization (surrogacy) from Georgia", dated April 11, 2016 and April 5, 2016. KhuRTsidze, Ia, Legal regulation of surrogacy in Georgia, en European Scientific Journal (2016), pp. 166 ss.

${ }^{34}$ Temporary law on the transfer of parenthood for children in Norway born through a surrogate mother abroad 2013.

${ }^{35}$ We must point out the position of Russia, whose order allows the surrogation, provided that there is no genetic link between the pregnant woman and the born (while otherwise there would be an attempt to circumvent, severely sanctioned, the legislation on adoptions), but that however it allows the parturient to prevail over the genetic parents, if she, for any reason, refuse to give them her child: cf. Court cost Russian Federation, May 15, 2012, n. 880-O.

36 The practice is expressly prohibited in 15 States (Austria, Estonia, Finland, France, Germany, Iceland, Italy, Moldova, Montenegro, Spain, Serbia, Slovenia, Sweden, Switzerland, Turkey); in 10 it is of uncertain admissibility or because it is forbidden by general norms or because of dubious legality (Andorra, Bosnia Herzegovina, Ireland, Latvia, Lithuania, Malta, Monaco, Romania, San Marino and Hungary), it is allowed in 7 (Albania, Georgia, Greece, the Netherlands, the United Kingdom, Russia and Ukraine) and is tolerated, finally, in 4 States, where it is not regulated (Belgium, Czech Republic, Luxembourg, Poland). Christiansen, Karin, Who is the mother? Negotiating identity in an Irish surrogacy case, en Medical Health Care Philos 18 (2015), 3, pp. 320ss.

${ }^{37}$ See the Children's Act, 2005 (hereinafter referred to as the principal Act), (Act No. 38 of 2005) Chapter 19: Surrogate Motherhood 292.

${ }^{38}$ See, Bill of Protection of Children Born from Assisted Reproductive Technologies Act. B.E., Subject No. 167/2553, trans. Chaninat \& Leeds Co., Ltd. (2014). See, Y. HIBINO, Y. SHIMAZONO, Becoming a surrogate online: "Message board" surrogacy in Thailand, 5 in Asian Bioethics Review, 5, 2013, pp. 58, (describing a surrogate mother's ability to live within her current income, but her desire to improve her own mother's living conditions with the otherwise unnecessary surrogacy funds).

${ }^{39}$ See in Illinois the Gestational Surrogacy Act del 2004 and in California the "surrogacy-friendly" was elaborated from the jurisprudence: Johnson vs. Calvert, Cal. Sup. Ct., 5 Cal4th 84, 851 P.2d 776 (1993), ed In re Marriage of Buzzanca, 
of commercial exploitation at a very high $\operatorname{cost}^{40}$.

The relevance of the issue from the point of view of human rights can then correctly be understood only considering that the use of maternity substitution is more and more often carried out in a different country and, in the majority of cases, poorer than the origin of the parent commissioners (we talk about international or global surrogacy). Although the reasons behind this form of "reproductive tourism" 41 are

61 Cal. App. 4th 1410, 72 Cal. Rptr.2d 280 (Ct. App. 1998), e poi codificato con il California Assembly Bill n. 1217 of 23 September 2012.

${ }^{40}$ Permanent Bureau, Hague Conference on Private International Law, A Preliminary Report on the Issues Arising from International Surrogacy Arrangements 7 (Prel. Doc. No. 10, 2012) p. 9 ss. D.L. HOFMAN, Mama's baby, daddy's maybe: A State-by-State survey of surrogacy laws and their disparate gender impact, in William Mitchell Law Review, 36, 2009, pp. 450ss. Trimmings - PBEAumont, cit. (n. 14). Wells-Greco, Michael, The status of children arising from inter-country surrogacy arrangements (The Hague, Eleven Publishing, 2015). For the case of Australia see: Millbank, Jenni, The new surrogacy parentage laws in Australia: Cautious regulation or "25 brick walls?", en Melbourne University Law Review 35 (2011), pp. 5 ss. ToBIn, John, To prohibit or permit: What is the (human) rights response to the practice of international commercial surrogacy?, en International \& Comparative Law Quarterly 63 (2014), pp. 318 ss. STUMCKе, Anita, Extraterritoriality and surrogacy: The problem of State and territorial moral sovereignity, en Surrogacy, law and human rights (London \& New York, Routledge, 2015), pp. 65 ss., and for United States: Mohapatra, Shyam, States of confusion: Regulation of surrogacy in the United States, en New cannibal markets: Globalization and cmmodification of the human body (El Boudamoussi, 2015).

${ }^{41}$ Patton, cit. (n. 26), pp. 513-522. Diel, E. G. A., Leihmutterschaft Und Reproduktionstourismus (Frankfurt, Wolfgang Metzner, 2014), pp. 72 ss. VAN BeERS, B. C., Is Europe "giving in to baby markets?", Reproductive tourism in Europe and the gradual erosion of existing legal limits to reproductive markets, en Medical Law Review 23 (2015), pp. 104 ss. CHERRY, A. L., The rise of the reproductive brothel in the global economy: Some thoughts on reproductive tourism, autonomy and justice, en University of Pennsylvania Journal of Law \& Social Change 17 (2014), pp. 258 ss.: “(...) since the 1990 s, we have seen the development of surrogacy, including gestational surrogacy, and the increasing normalization and globalization of its practice (...)". WHITTAKER, A., Merit and money: The situated ethics of transnational commercial surrogacy in Thailand, en International Journal of Feminist Approaches to Bioethics 7 (2014), pp. 102 ss. CaAmaño, J. M., International commercial gestational surrogacy through the eyes of children born to surrogacy in Thailand: A cry for legal attention, en Boston University Law Review 96 (2016), pp. 57 ss. Kindregan, C. - White, D., International fertility tourism: the potential for stateless children in cross-border commercial surrogacy arrangements, en Suffolk Transnational Law Review 36 (2013), pp. 528 ss. KeYES, M., Cross border surrogacy agreements, en Australian Journal of Family Law 26 (2011), 1, pp. 30 ss. Donchin, A., Reproductive tourism and the quest for global gender justice, in Bioethics 10 (2010), 3, pp. 323-332. SindRES, D., Le tourisme procréatif 
certainly numerous, surrogate motherhood is mostly carried out abroad because it is operated in more advantageous economic conditions ${ }^{42}$ and/ or because this allows circumventing any impediments of legal nature, provided for by the domestic law of the country of origin of the aspiring parents. Such impediments may consist in the general prohibition of resorting to the practice, or in various forms of restriction related to sexual orientation or the age of the intended parents ${ }^{43}$.

\section{RECOGNITION TECHNIQUES AND LIMITATION OF INTERNATIONAL PUBLIC ORDER}

The so-called International subrogation poses first of all questions of conflicts between jurisdictions in the respective reference values, where the persons concerned constitute a valid relation of filiation abroad to request, at a later date, recognition in the State of citizenship or in that in which they habitually reside, in order to circumvent the restrictions imposed therein. It should be noted that, from the point of view of the state system, it is a matter of verifying whether the conditions exist for ascertaining and constituting directly in the State, determining its effects through the traditional rule of conflict, a relationship of filiation that originates from surrogate motherhood rather, the problem of assessing whether it is possible to recognize, in the forum, the validly constituted partnership relationship in a third State and, if necessary, proceed with the transcription of the birth certificate in the public registers of civil status. Naturally, every conflict system has its own solutions in terms of

et le droit international privé, en Journal du Droit International (2015), pp. 432 ss. FulChIRON, H., La lutte contre le tourisme procréatif: vers un instrument de coopération internationale?, en Journal du Droit International (2014), pp. 564 ss. KINDREGAN, C. P., International fertility tourism: The potential for stateless children in cross-border commercial surrogacy arrangements, en Suffolk Transnational Law Review 36 (2013), pp. 527 ss. InHORN, M. - PATRIzIO, P., Reproductive tourism as reproductive exile, en Fertility and Sterility 92 (2009), p. 904 ss. Mouly, J., La "délocalisation procréative": fraude à la loi ou habileté permise?, en Recueil Dalloz (2014), pp. 2419 ss. SANGER, C., Developing markets in baby-making: In the matter of baby M, en Harvard Journal Law Gender 30 (2007), pp. 94 ss.

${ }^{42}$ STORrow, R. F., Quests for conception: Fertility tourists, globalization and feminist legal theory, en Hastings Law Journal 57 (2005-2006), pp. 295 ss. PenNings, G., Reproductive tourism as moral pluralism in motion, en Journal of Medical Ethics 28 (2002), pp. 338 ss. Crozier, G. K. D. - Martin, D., How to address the ethics of reproductive travel to developing countries: A comparison of national self sufficiency and regulated market approaches, en Developing World Bioethics 13 (2012), pp. 46 ss.

${ }^{43}$ See a study of legal parentage and the issues arising from international surrogacy arrangements, Prel. Doc. N. 3C, mar. 2014, par. 139, 143. 
the attribution of legal force in the forum to foreign decisions or acts, in order to reach a result coordinated with the State of origin. These are techniques, alternatives to those of spatial location of the case, which aim to overcome the antinomies between individual system $s^{44}$ the techniques referred to meet the common obstacle represented by the exception of international public order ${ }^{45}$.

If the people who invoke the recognition of the filii status, validly constituted abroad, are foreign citizens, the limit of the international public order ${ }^{46}$ could operate in the sense that the set of principles underlying the entire ordering structure in matters of filiation ${ }^{47}$-included the prohibition of surrogacy of maternity and the attribution of same to the woman giving birth-rises to an insuperable obstacle from the external normative values with it incompatible ${ }^{48}$.

In the case of assisted surrogation that determined the birth of a newborn entrusted to a homosexual couple ${ }^{49}$ at the end of the gestation, it could be further supported by the principles of the internal legal system that, in relation to filiation, refer explicitly to the figures of mother and father, if not also, in even more restricted terms, husband and wife as fundamental values of every democratic country. Naturally, the limit of the public order could be withdrawn in case of subrogation, if we think of the hypothesis in which one of the two individuals is the biological parent and therefore the action is aimed at requesting recognition of the validly constituted parenting relationship ${ }^{50}$.

${ }^{44}$ Trimmings, K. - Beaumont, P., cit. (n. 16), pp. 628ss.

${ }^{45}$ Fulchiron, H. - Martín Calero, G., L'ordre public à l'èpreuve des droits de l'enfant: non à la GPA internationale, oui à l'intlgration de l'enfant dans sa famille: à propos de la dècision du "tribunal Supremo" espagnol du 6 fivrier 2014, en Revue Critique de Droit International Privè 103 (2015), pp. 532 ss.

${ }^{46}$ MaYer, C., Ordre public und Anerkennung der rechtlichen Elternschaft in internationalen Leihmutterschaftsfällen, en Rabels Zeitschrift für ausländisches und uropeanonals Privatrecht 78 (2014), pp. 552 Ss.

${ }^{47}$ SCHWARZ, B., Die Verteilung der elterlichen Sorge aus erziehungswissenschaftlicher und juristischer Sicht (Wiesbaden, VS Verlag, 2011), pp. 42 ss. KAISER, D., Elternglück durch Fremdspende und Leihmutterschaft?, en Festschrift für Gerd Brudermüller (München, C.H. Beck, 2014), pp. 358 ss.

${ }^{48}$ STORROw, R., The phantom children of the new republic: International surrogacy and the new illegitimacy, en American University Journal of Gender, Social Policy and the Law 20 (2012), 3, pp. 564 ss.

${ }^{49}$ Koffeman, N., Morally sensitive issues and cross-border movement in the EU: The cases of reproductive matters and legal recognition of same-sex relationships (Antwerp, Intersentia, Oxford, 2015).

${ }^{50}$ BuCHeR, A., L'ordre public et le but social des lois en droit international privé, en Recueil des cours de l'Académie de Droit International de la Haye 239 (1993), pp. 47 
The case would present an even more intense link with the forum than the hypothesis, considered above, of a heterosexual couple of foreign nationality. In effect, the prohibition of surrogacy and the underlying ethical-normative values, elevated to the principle of international public order, would prevent a fortiori, by virtue of this more intense bond, the recognition in the forum of family legal situations constituted abroad ${ }^{51}$. Moreover, in the case of statelessness of a minor born of maternity surrogacy with genetic material unrelated to the couple requesting recognition, national authorities could reject the action of recognition of status, declare the condition of abandonment of the minor and therefore his status of adoptability.

\section{BAN ON SALE OF CHILDREN AND INTERNATIONAL ADOPTION}

Considering the commercial nature that characterizes most of the global surrogacy agreements ${ }^{52}$, first of all there are profiles of incompat-

ss. Courbe, P., L'ordre public de proximité, in Le droit international privé: Esprit et méthode, en Melangés en l'honneur de Paul Lagarde (Paris, Dalloz, 2005), pp. 227 ss. Mosconi, F., Exceptions to the operation of choice of law rules, en Recueil des cours de l'Académie de Droit International de la Haye 217 (1989), pp. 28 ss.

${ }^{51}$ For this recognition see: the scope of Regulation (EC) No 2201/2003 concerning jurisdiction and the recognition and enforcement of judgments in matrimonial matters and the matters of parental responsibility (Brussels II bis) you can only find the attribution, the exercise, the delegation and the restriction or termination of parental responsibility (Art 1.1.b). VAN BALlEGOOI, W., The nature of mutual recognition in uropean law (Oxford, Intersentia, Antwerp, 2015). STORME, M., Harmonisation of civil procedure and the interaction with substantive private law, en Civil litigation in a globalizing World (The Hague, T.M.C. Asser Press, 2012), pp. 142 ss. The Regulation (EC) No 593/2008 on the law applicable to contractual obligations (Rome I) is not applicable, since questions involving the status or legal capacity of natural persons (Art 1.2.a) and obligations arising out of family relationships (Art 1.2.b) are expressly excluded from the scope of this regulation. The latter is stated in Regulation (EC) No 864/2007 on the law applicable to noncontractual obligations (Rome II) as well, hence this regulation also being nonapplicable. Ahern, J. - BINCHy, W., The Rome II Regulation on the law applicable to non-contractual obligations (Leiden, Brill, 2009). RüHL, G., Contractual obligations (PIL), en Encyclopedia of european private law (Oxford, Oxford University Press, 2012). EInSELE, D., Kapitelmarketrecht und Internationales Privatrecht, en Rabels Zeitschrift für ausländisches und internationales Privatrecht 81 (2017). DicKInson, A., The Rome II Regulation: The law applicable to non-contractual obligations updating supplement (Oxford, Oxford University Press, 2010). Carballo Piñeiro, L., Actio pauliana and european integration: A proposal regarding applicable law, en Revista Espaňola de Derecho Internacional 64 (2012), 1, pp. 45 ss.

52 Ramskold, L. A. - Posner, M. P., Commercial surrogacy: How provisions 
ibility with respect to the ban on the sale of minors and the legislation on international adoption ${ }^{53}$.

The practice in question would seem to represent a violation of $\mathrm{Ar}$ ticle 35 of the Convention on the Rights of the Child ${ }^{54}$, integrating the case referred to in art. 2 letter (a) of the Optional Protocol on the sale of children ${ }^{55}$, child prostitution and pornography representing children

of monetary and powers of international law can prevent exploitation of gestational surrogates, en Journal of Medical Ethics 39 (2013), 6, pp. 398 ss. Ryznar, M., International commercial surrogacy and its parties, en John Marshall Law Review 43 (2010), 4, pp. 1012 ss. Scherman, R. - Misca, G. - Rotabi, K. - Selman, P., Global commercial surrogacy and international adoption: Parallels and differences, en Adoption and Fostering 40 (2016), 1, pp. 22 ss.

${ }^{53}$ See, Convention of 29 May 1993 on protection of children and co-operation in respect of intercountry adoption in force from $1^{\text {st }}$ May 1995. MOHÁpatra, S., Adopting an international Convention on surrogacy. A lesson from intercountry adoption, en Loyola University Chicago International Law Review 13 (2015), 1, pp. 27 ss. See also: The inter-American Convention on the international return of children of 4 November 1994. Hevia, M., Surrogacy, privacy and the American Convention on Human Rights, en Journal of Law and the Biosciences (2018), pp. 378 ss. STHOEGER, E., International child abduction and children's rights: Two means to the same end, en Michigan Journal of International Law 32 (2011), pp. 512 ss. Surrogacy has not yet been discussed by the Inter-American Court of Human Rights (IACtHR).Thus, I examine this question under the framework of the 2012 IACtHR reproductive rights landmark decision in Artavia Murillo v. Costa Rica (Artavia Murillo et al. ("In vitro fertilization") v. Costa Rica, IACtHR (ser. C) No. 257 (Nov. 28, 2012): where the Court held that: "(...) a complete ban on assisted reproductive technologies interferes with the right to a private and family life, which comprises the decision to become a parent, as well as access to the means to materialize that private decision (...)". See in argument: BASSAN, S., Shared responsibility regulation model for cross-border reproductive transactions, en Michigan Journal of International Law 37 (2016), pp. 300 ss.: "(...) the perspective of Article 16 (2) of the Convention, this objection to surrogacy seems to appeal to public order or morality as a reason to restrict access to surrogacy (...) the reference to morality or common good should not necessarily be linked with the values of the majority, namely with positive morality (the fact that certain values are shared by themajority does not say anything on whether the law should enforce them); nor can "public order" mean just order (...)". COHEN, G., Transplant tourism: The ethics and regulation of international markets for organs, en Journal of Law Medical \& Ethics 41 (2013), pp. 272 ss. DE Jesus, L. M., The interAmerican Court on Human Rights Judgment in Artavia Murillo v. Costa Rica and its implications for the creation of abortion rights in the inter-american system of human rights, en Oregon Review of International Law 16 (2014), pp. 225 ss.

${ }^{54}$ Recalling also in Dublin III Regulation, Regulation (EC) No. 504/2013 of 26 June 2013 (recast Dublin II Regulation).

55 Smolin, D., Surrogacy as the sale of children: Applying lessons learned from 
in $2000^{56}$. It is in fact qualifiable as a transaction through which a child is transferred from one person or group of people to another or more persons, upon payment of a fee ${ }^{57}$. In Australia, it is no coincidence that the subrogation of maternity is forbidden ${ }^{58}$ precisely because it is considered to be in conflict with national legislation ${ }^{59}$.

adoption to the regulation of the surrogacy industry's global marketing of children (20152016), en Pepperdine Law Review 43 (2016), pp. 267 ss.

${ }^{56}$ ARTS, K., Twenty-five years of the United Nations Convention on the Rights of the Child: Achievements and challenges, en Netherlands International Law Review 61 (2014), 3, pp. 268 ss.

An example is Article 10(2), on family reunification, which clarifies that: “(..) the child and his or her parents' right to leave any country can only be restricted by law and if necessary 'to protect the national security, public order (ordre public), public health or morals or the rights and freedoms of others and are consistent with the other rights recognized in the present Convention". Similar clauses are included in Article 13(2) on the freedom of expression, Article 14(3) on the freedom of thought, conscience and religion, and Article 15(2) on the freedom of association and peaceful assembly. The combination of the two elements-by law and if necessaryis important as sometimes national law plainly allows for derogations on a much too broad scale. An example is Zimbabwe on which, in its Concluding Observations of 1996, the CRC Committee made critical remarks in this regard exposing that: “(...) section 23 of the Constitution (...) allows for derogations in important areas such as adoption, marriage, divorce and other matters of personal law and prevents, inter alia, girls from having inheritance rights (...)". see also the Optional Protocol to the Convention on the Rights of the Child on a Communications Procedure, UNGA Res. 66/138, adopted 19 December 2011, published in UN Doc. A/RES/66/138, 27 January 2012, Art. 15(1); UN Committee on the Rights of the Child, 'Concluding Observations of the Committee on the Rights of the Child: Zimbabwe, UN Doc. CRC/C/15/Add.55, 7 June 1996, para. 12.82. Lundy, L., et al., Incorporation of the United Nations Convention on the Rights of the Child in law: A comparative review, en International Journal of Children's Rights 21 (2013), pp. 444 ss.

57 See in argument in particular: Dethloff, N., Leihmütter, Wunscheltern und ihre Kinder, in Juristenzeitung (2014), pp. 924 ss. BRITZ, G., Das Grundrecht des Kindes auf staatliche Gewährleistung elterlicher Pflege und Erziehung-jüngere Rechtsprechung des Bundesverfassungsgerichts, en Juristenzeitung (2014), pp. 1070 ss. ENGEL, M., Internationale Leihmutterschaft und Kindeswohl, en Zeitschrift für Europäisches Privatrecht 5 (2014), pp. 539 ss.

${ }^{58}$ As we can see from the next cases: Collins v Tangtoi [2010]; O'Connor v Kasemsarn [2010]; Dennis v Pradchaphet [2011]; Dudley v Chedi [2011]; Johnson v Chompunut [2011]; Hubert v Juntasa [2011]; Findlay v Punyawong [2011]; Edmore v Bala [2011]; Gough v Kaur [2012]; Ellison v Karnchanit [2012]; Mason \& Mason and Anor [2013].

59 See the next cases: Gand G (2012) EWCH 1979; Re W (2002) EWCA Civ 715; Re N (2007) EWCA Civ 1053; Re T (2011) EWHC 33; J and G (2013) EWCH 1432; Marriage of F (1989) FLC 92-031; Talbot and Norman (2012) FamCA 96; ND and BM (2003) FamCA 469, according to Western Australia surrogacy act 2008 
In this sense, the Committee on the Rights of the Child also seems to move, which in 2014, in the concluding observations concerning the report presented by India ${ }^{60}$, underlined how the "widespread commercial use of surrogacy, including international surrogacy" ${ }^{61}$, could represent a violation of "various rights of children and can lead to the sale of children" 62 . Opportunities for exploitation are of obvious concen, surrogates in India have been interviewed for their perspectives on the practice. Extreme poverty, a dearth of work opportunities, and financial desperation are often cited as reasons why Indian women pursue surrogacy as a work option. The Committee reached similar conclusions in 2013, in its response to the second periodic report of the United States, in which it signaled its concern with regard to "the fact that payments before birth and other expenses to birth mothers, including surrogate mothers, continue to be allowed, thus impeding effective elimination of the sale of children for adoption; (and) the absence of federal legislation with regard to surrogacy, which if not clearly regulated, amounts to sale of children (...)"63.

(WA) and parentage act of 2004. See: BusBY, K., Of surrogate mother born: Parentage determinations in Canada and elsewhere, en Canadian Journal of Women and the Law 25 (2011), 2, pp. 286 ss. Everingham, S., Australians' use of and attitudes to altruistic and commercial surrogacy: Results of a national survey, en Families, policy and the law: Selected essays on contemporary issues for Australia (Melbourne, Australian Institute of Family Studies, 2014), pp. 9 ss. Millank, J., Resolving the dilemma of legal parentage for Australians engaged in international surrogacy, en Australian Journal of Family Law 27 (2013), 2, pp. 138 ss.

60 Pande, A., Wombs in labor. Transnational commercial surrogacy in India (Columbia, Columbia University Press, 2015).

${ }^{61}$ Munjal-ShanKar, D, Identitifying the "real mother" in commercial surrogacy in India, en Gender Technology and Development 18 (2014), 3, pp. 390 ss. Committee on the Rights of the Child, Concluding Observations on the Consolidated Third and Fourth Periodic Reports of India (CRC/C/IND/CO/3-4) (2014), at para 57(b). Committee on the Rights of the Child, Concluding Observations on the Second Periodic Report of the United States of America Submitted Under Article 12 of the Optional Protocol to the Convention on the Sale of Children, Child Prostitution and Child Pornography, (CRC/C/OPSC/USA/CO/2) (2013). Committee on the Rights of the Child, General Comment No 14 (2013), On the Right of the Child to Have his or her Best Interests taken as a Primary Consideration (art 3, para 1), (CRC/C/ $\mathrm{GC} / 14)$, at para 49.

${ }^{62}$ Concluding observations on the report submitted by India under article 12, paragraph 1, of the Optional Protocol to the Convention on the Rights of the Child on the sale of children, child prostitution and child pornography (CRC/C/OPSC/ IND/CO/1), 7 July 2014, par. 23, lett. (f).

${ }^{63}$ Committe on the rights of the child, Concluding observations on the second periodic report of the United States of America submitted under article 12 of the Optional Protocol to the Convention on the sale of children, child prostitution and child pornography, (CRC/C/OPSC/USA/CO/2), 2 July 2013, par. 29, lett. (a) e 
The subrogation of maternity for consideration seems to be contrary to art. 4 (c) 3 of the Hague Convention on the Protection of Children and Cooperation in the Field of International Adoption ${ }^{64}$, pursuant to which the consent to adoption by the biological parent ${ }^{65}$ should not be induced "by payment or compensation of any kind". The same Convention on the rights of the child called for in art. 21 lit. (d) regulation of the institution of adoption aimed at excluding any "improper financial gain for those involved in it" 66 .

(b). SpIVAK, C., The law of surrogate motherhood in the United States, en American Journal of Comparative Law 58 (2010), pp. 100 ss. Hinson, D., Surrogacy across America: Both the law and the practice, en Family Advocate 34 (2011), 2, pp. 34 ss. According to SMITH, R., The third Optional Protocol to the UN Convention on the Rights of the Child?. Challenges arising transforming the rhetoric into reality, en International Journal of Children's Rights 21 (2013), pp. 308 ss, “(...) an omission in the third optional protocol is the lack of provision for a neutral curator ad litem, guardian, or litigation friend to be appointed to help the child with the communication process (...)". See also: NGO Group for the CRC, 'Joint NGO Submission to the OpenEnded Working Group on an Optional Protocol to the Convention on the Rights of the Child to Provide a Communications Procedure, October 2010. Egan, S., The new complaints mechanism for the Convention on the Rights of the Child: A mini step forward for children?, en International Journal of Children's Rights 21 (2013), pp. 6 ss. Ainsworth, S. L., Bearing children, bearing risks: Feminist leadership for progressive regulation of compensated surrogacy in the United States, en Washington Law Review 89 (2014), pp. 1078 ss. Guzman, V. R., A comparison of surrogacy laes of the U.S. To other countries: Should there be a uniform federal law permitting commercial surogacy?, en Houston Journal of International Law 38 (2016), 2, pp. 624 ss.

${ }^{64}$ Henaghan, M. - Ballantyne, M. R., International child abduction, inrercomunity adoption and international commercial surrogacy, en Routledge handbook of family law and policy (London \& New York, Routledge, 2014), pp. 385 ss. Rotabi, K S. BROMFIELD, N. F., From intercountry adoption to global surrogacy: A human rights history and new family frontiers (London \& New York, Routledge, 2016).

${ }^{65}$ Lamm explains that: “(...) adoption implies a post-partum judicialization, and all this situation of judicialization without a legal framework to provide legal security, and the fact of doing so after the birth of the child, which implies that a period necessarily elapses until the parentage in favor of the intended parents is determined, gives rise to a series of violations of different rights of children born through this technique. What happens if, after the children are born, the intended parents repent? What happens if a child is born with malformations or diseases? What happens if the intended parents die or divorce or separate? What happens if the one who does not have a legal link dies, leaving the child deprived of, for example, the ability to inherit? Or if the one who dies is the one who did have a legal bond and the child is left without emplacement?The casuistry is immense, being impossible to predict all the possible violations (...)". Lamm, F., Argentina, en International surrogacy arrangements. Legal regulation at the international level (Oxford, Oxford University Press, 2013).

${ }^{66}$ In the same spirit: Dublin III Reg., Reg. (EC) N. 604/2013 of 26 June 2013 (recast Dublin II Reg.). Scutz, R., The hague child (Act) adbuction Convention: A 
However, the arguments developed to distinguish surrogate motherhood from the sale of children are different ${ }^{67}$. A first argument moves from considering the child who is not genetically linked to the surrogate mother as "something" that does not belong to her and that therefore she can not "self" 68 . Naturally this objection would apply exclusively to subrogation for gestation only. Even in these cases, however, it clashes with the finding that, irrespective of the genetic link, the surrogate mother provides biological resources essential to the development of the child, which is also physically connected by an organ-the placenta-compound in part from cells of maternal origin and partly from cells of fetal origin, a tangible sign of the natural link between those who give birth and those who are born ${ }^{69}$. The impossibility of establishing a pre-eminence, in the process of development of the embryo and the fetus, between genetic patrimony, on the one hand, and biological contribution, on the other, already reveals the limits of the described topic, which, however, does not tackles the heart of the problem, represented by the payment of a fee in favor of mère porteuse. Furthermore, the letter of the provision pursuant to art. 2 (a) of the Protocol appears very clear in referring to the transfer made by any person: in fact, when this is done at the profit, it is absolutely irrelevant that those who transfer (but also who receives) have or not a genetic link with the child ${ }^{70}$.

critical analysis, Hart Publishing, (Oregon, Oxford \& Portland, 2014). BucK, T., International child law (London \& New York, Routledge, 2014), pp. 362 ss. Verhellen, E., The Convention on the rights of the child (London \& New York, Routledge, 2015).

${ }^{67}$ Nichol, B. M., A child without a country. Dissolving the statelessness of children born through surogacy, en Michigan State Law Review 907 (2016), pp. 914 ss.

${ }^{68}$ LARKEY, A. M., Redefining motherhood: Determining legal maternity in gestational surrogacy contracts, en Drake Law Review 52 (2003), 3, pp. 615 ss.

69 Zermatten, J., The best interests of the child principle: Literal analysis and function, en International Child Rights 18 (2010), pp. 484 ss. BLAuwoff, R. - FroHn, L., International commercial surrogacy arrangements: The interests of the child as a concern of both human rights and private international law, en Fundamental rights in international and european law (The Hague, T.M.C. Asser Press, 2016), pp. 212 ss. Crawshaw, M., et. al., What are children's "best interests" in international surrogacy? A social work perspective from the UK, en Babies for sale: Transnational surrogacy, human rights and the politics of reproduction (Zed Books, 2017), pp. 165 ss. AKILA Chounhury, C., Transnational commercial surrogacy: Contracts, conflicts and the prospects of international legal regulation (Oxford, Oxford University Press, 2016). Ní GHráinne, B., et. al., A public international law approach to safeguard nationality for surrogate-born children, en Legal Studies 37 (2017), 37, pp. 326 ss.

${ }^{70}$ Henrich, D., Leihmütterkinder: Wessen Kinder?, en Praxis des Internationalen Privat-und Verfahrensrechts (2015), pp. 230 ss. 
A second point of complexity is that of the contract between the commissioning parents and the surrogate mother, if it is actually aimed at carrying out a service (the gestation) and not the purchase of a child ${ }^{71}$. To ensure that the compensation is paid for the service and not the purchase price of the newborn, it would be sufficient for some to provide that the fee is paid regardless of the successful outcome of pregnancy, therefore, for example, even in the case of abortion ${ }^{72}$. For others it would even be sufficient to establish a maximum amount for the consideration. It seems obvious to the writer that in the contractual relationship established by a surrogate agreement a part (the parent clients) requires the other (the pregnant woman) to renounce the rights on the child who will give birth: this evidently means that "(...) intended parents have little interest in the surrogate's services without this relinquishment. It is clear, therefore, that what is at stake in a surrogacy contract is right to a child, and not merely the performance of a service (...)" ${ }^{m 3}$.

\section{BAN ON MARKETING THE HUMAN BODY OR ITS OWN PARTS}

The economic nature of the agreement then calls into question those provisions that recognize a violation of human dignity in the reduction of goods for the exchange of goods and values that do not in themselves have a commercial nature.

In this sense, the Oviedo Convention on Human Rights and Biomedicine of 1997 and the Charter of Fundamental Rights of the European Union, which ratify articles 21 and $3^{74}$, the prohibition on making the human body and its parts as such a source of profit. This principle has undergone several more precise declinations: with reference, for example, to the donation of tissues and cells, Directive 2004/23/EC of the Euro-

${ }^{71}$ MAYER, C., Sachwidrige Differenzierungen in internationalen Leihmutterschaftsfällen, en Praxis des Internationalen Privat-und Verfahrensrechts 1 (2014), pp. 58 ss.

${ }^{72}$ Hague Conference on Private International law. 2012. Preliminary report on the issues arising from international surrogacy arrangements. The Hague: Permanent Bureau, 2013. Mcleod, C., et. al., A Hague Convention on contract pregnancy (or "surrogacy"): Avoiding ethical inconsistencies with the Convention on adoption, en International Journal of Feminist Approaches to Bioethics 7 (2014), pp. 228 ss.

${ }^{73}$ SCherpe, J. M., et. al., Eastern and Western perspective on surrogacy (Antwerp, Oxford, Intersentia, 2018). MARGALIT, Y., In defense of surrogacy agreements: A modern contract law perspective, en William \& Mary Journal Women \& Law 21 (2014), pp. 424 ss. Boyce, A. K., Protecting the voiceless: Rights of the child in transnational surrogacy agreements, en Suffolk Transnational Law Review 36 (2013), pp. 650 ss.

${ }^{74}$ Bantekas, I. - OetTe, L., International human rights law and practice (Cambridge, Cambridge University Press, 2013). Gerber, P., et. al., Surrogacy, law and human rights (London \& New York, Routledge, 2015). 
pean Parliament and of the Council requires Member States to work "to guarantee voluntary and free donations of tissues and cells"75 and "that the procurement of tissues and cells as such takes place on a non-profit basis"76. Again, with a Resolution of 2005, the European Parliament has specified that the sale of female gametes should always be forbidden, recognizing that the collection of oocytes constitutes a high medical risk for the life and health of women ${ }^{77}$ and that, despite these risks, the earning perspective encourages the provision of the same, also considering the relative scarcity of donors ${ }^{78}$. The traffic of organs ${ }^{79}$ is then forbidden by art. 22 of the Additional Protocol to the Oviedo Convention on the transplantation of organs and tissues of human origin in 2002 and is the specific object of the Convention against trafficking in human organs.

These regulations, or rather the principles that inspire it, offer a further response to those who believe that the exchange, which is carried out through the subrogation agreement, concerns the service and does not deliver it against the payment of a minor. Even if this assumption were true, the opposition of the practice with respect to the rules of international law would not be excluded. Still, it does not seem relevant to note that, by itself, the surrogacy of maternity is not comparable to the sale of an organ, not resulting in an irreversible impairment of the woman's body. The binding and soft law standards mentioned, also referring to the removal of cells, tissues and gametes (which, as such, does not entail a permanent impairment) show that the underlying rationale is differ-

75 BRUNET, L., et al., A comparative study on the regime of surrogacy in EU member States (2013), PE 474.403, pp. 157 and 194.

${ }^{76}$ European Parliament and Council, Directive 2004/23/EC of 31 March 2004, on the definition of quality and safety standards for the donation, procurement, control, processing, storage, distribution and distribution of fabrics and human cells, art. 12. Pennings, cit. (n. 42), pp. 56 ss, noting that “(...) when countries abolish [sperm] donor anonymity or make payment for donors illegal, this has an impact on the number of candidates" and that Canadian regulations prohibiting payment have led to the fact that $80 \%$ of children born in Canada of donor-sperm have an American donor; interestingly, this means that these donors were paid for their donation (...)".

77 In the same spirit of orientation: European Parliament Resolution of 17 December 2015 on the Annual report on human rights and democracy in the world 2014 and the European Union's policy on the matter (2015) 2229 (INI), 17 Dec. 2015 P8_TA (2015) 0470.

78 European Parliament, Resolution on the trade in human egg cells, P6_ TA(2005)0074, 10 marzo 2005.

${ }^{79}$ Chuang, J. A., Rescuing trafficking from ideological capture: Prostitution reform and anti-trafficking law and policy, en University of Pennsylvania Law Review 159 (2010), pp. 1655 ss. 
ent and consists in preventing the commercialization of non-commercial goods and, implicitly, the exploitation of the poorest sections of the population.

Some believe that regulating the use of international surrogacy can be an instrument adopted under the auspices of the International Labor Organization (ILO). A regulation built "through the lens of labor rights" would have the advantage of not forcing legislators to choose one of the two opposing positions: to recognize maximum contractual freedom in the matter or to impose an absolute ban on the fear of abuse. The limitations of such a solution are evident, however, if one considers that, focusing exclusively on the need to protect the surrogate mother, she would not be able to take into account other relevant subjective legal positions, above all those of the child.

In our opinion, it is lacking both at international and EU level the need for regulation similar to that in the field of international adoption and therefore an instrument establishing a framework for international cooperation, placing particular emphasis on the need for substantial guarantees and procedural, and which leaves the task of establishing detailed legislation for bilateral diplomacy. In order to ensure uniformity in the two subjects, it would in particular be essential that a treaty on surrogacy be, like the Hague Convention on International Adoption, neutral with respect to that practice, or does not necessarily require its recognition by the Member States, but limits itself to demanding that: “(...) before a contract pregnancy arrangement occurs, the two states involved in the arrangement agree to it and the receiving state allows any resulting child to cross its borders and be or become the legal child of the commissioning couple (...)" 81 .

Certainly, however, the different perspective at the origin of the two institutes can not but permeate the debate. It is no accident, in fact, that the adoption of minors without a family has never been in itself a controversial institution, being also expressly provided for by the Convention on the rights of the child in art. $21^{82}$. In fact, the institution of interna-

${ }^{80}$ Choudhury, C. A., The political economy and legal regulation of transnational commercial surrogate labor, en Vanderbilt Journal of Transnational Law 48 (2015), pp. 5 ss. Allan, S., The surrogate in commercial surrogacy, en Surrogacy, law and human rights (Aldershot, Ashgate Publishing, 2015).

${ }^{81}$ STARK, B., Transnational surrogacy and international human rights, en ILSA Journal of International \& Comparative Law 18 (2012), pp. 370 ss.

82 Funcke, D. - Thorn, P., Die gleichgeschlechtliche Familie mit Kindern (Bielefeld, Transcript-Verlag, 2010), pp. 162 ss. 
tional adoption is designed to pursue a "humanitarian" purpose and from this logic it remains outside the existence of a commercial transaction.

It is once again evident, then, that the central point of the question is the profit nature of most subrogation agreements: this is the profile that, we have seen, raises problems of incompatibility with current international law ${ }^{83}$. However, it does not seem realistic to imagine that an absolute ban on paid surrogacy can obtain a sufficiently generalized consensus, given the growing number of states for which procreative tourism appears to be rather lucrative. Moreover, an instrument that does not completely ban subrogation is considered by many to be the lesser evil: it would in fact be preferable to regulate the abuse, rather than the total absence of rules ${ }^{84}$. Indeed, a rumor points out that a ban on commercial surrogacy ${ }^{85}$ would end up increasing the black market

${ }^{83}$ STEHR, E., International surrogacy contract Regulation: National governments and international bodies misguided quests to prevent exploitation, en Hastings International \& Comparative Law Review 35 (2012), pp. 288 ss.

${ }^{84}$ Neal, M. E., Protecting women: Preserving autonomy in the commodification of motherhood, en William \& Mary Journal of Women \& Law 18 (2011), pp. 612 ss.

${ }^{85}$ In particular, Article 21 of the Ovideo Convention is also explicit that "The human body and its parts shall not, as such, give rise to financial gain". Relevant to the preconception stage, Article 18(1) states that "Where the law allows research on embryos in vitro, it shall ensure adequate protection of the embryo (...)". See in argument: Ladomato, D., Protecting traditional surrogacy contracting through fee payment regulation, en Hastings Women's Law Journal 21 (2012), pp. 246 ss. Mutcherson, K. M., Welcome to the wild west: Protecting access to cross border fertility care in the United States, en Cornell Journal of Law \& Public Policy 22 (2012), pp. 352 ss. Vincent, C. - Aftandilian, A. D., Liberation or exploitation: Commercial surrogacy and the Indian surrogate, en Suffolk Transnational Law Review 36 (2013), pp. 672 ss. ((...) in countries where commercial surrogacy is allowed, these basic fundamental rights, as enshrined in multiple international treaties and conventions, should be protected by domestic law and regulations (...)"). REICH, J. B. - SwINK, D., Outsourcing human reproduction: Embryos \& surrogacy eervices in the cyberprocreation era, en Journal of Health Care Law \& Policy 43 (2011), pp. 242 ss.: “(...) we contend that while the Internet increased the availability of, and the market for, human embryos and surrogacy services to a larger audience than ever envisioned, it also created significant and unimagined legal concerns for embryo donors, suppliers, surrogates and surrogate providers (...)". NELSON, E., Global trade and assisted reproductive technologies: Regulatory challenges in international surrogacy, en Journal of Law Medical \& Ethics 41 (2013), pp. 242 ss. LuCKeY, C., Commercial surrogacy: Is regulation necessary to manage the Industry?, en Wisconsin Journal of Law Gender \& Society 13 (2011), pp. 238 ss.. “discussing The Hague Convention's goal to address international adoption through the elimination of child trafficking and abduction (...) in the international adoption context, the Hague Convention serves to protect adopted children who are similarly situated in context and interest to the resulting 
and the sale of children, as well as worsening the conditions of exploitation of mothers.

On this point, however, it seems very difficult for the writer to take a position of openness. The legislation referred to clearly militates against such a solution. It is true that technically none of the provisions cited contains a provision of jus cogens: a treaty therefore could well regulate the specific case of subrogation as a case distinct from that prohibited by art. 2 (a) of the 2000 Protocol and the legislation on adoption. However, the aforementioned instruments are indicative of a widespread sensitivity among the States, which in fact informs of itself a structured regulatory corpus (not only with regard to the prohibition on the sale of children and adoption, but also with reference to the prohibition of human body and its parts as such), whose uniformity deserves to be preserved.

Therefore, that of the profit nature of the practice remains a crucial issue that can hardly be resolved at the international level. However, there is no doubt that other aspects of the institution of adoption can provide a guide to imagine, at least in outline, the contours of a possible international regulation on maternity surrogation. In particular, such legislation should regulate the consensus of the surrogate mother similarly to that of the biological parent for adoption: in this regard, it should be recalled that art. 4 (c) 4 of the Hague Convention provides that the consent of the biological mother to adoption is given after the birth. Furthermore, a possible international regulation on surrogacy should, for example, provide for the assessment of the couple's suitability to become parents of the child ${ }^{86}$.

\section{IMPACT OF FUNDAMENTAL RIGHTS ON THE DISCIPLINE OF} INTERNATIONAL SUBROGATION: THE JURISPRUDENCE OF THE EUROPEAN Court of Human Rights

The jurisprudence of the ECtHR on the private international law of the family has become a sure fact for many years now. The ECtHR does

children of surrogacy, providing support for a similar regulatory approach (...) with adoption, the UN found that the only way to adequately protect the parties was to legalize international adoption and then define its scope. A similar approach would be beneficial to protect international surrogacy relationships (...)”. Lin, T., Born lost: Stateless children in international surrogacy arrangements, en Cardozo Journal of Internatonal \& Comparative Law 21 (2013), pp. 548 ss.

${ }^{86}$ Benicke, C., Kollisionsrechtliche Fragen der Leihmutterschaft, en Das Standesamt (2013), pp. 102-111. 
not show particular deference to national systems on conflicts of laws considered lato sensu, not being able to draw convincing arguments from the alleged neutrality of its methods of coordination between laws or legal systems. It was therefore foreseeable that the Court itself-comparing this discipline with conventional obligations like any other area of domestic law ${ }^{87}$-had to rule on restrictive state guidelines that prevent the recognition of filiation status resulting from surrogate maternity ${ }^{88}$.

This, in fact, occurred in the Labassee v. France and Mennesson $v$. France of 26 June 2014 judgments ${ }^{89}$. The subsequent sentence Paradiso and Campanelli v. Italy, issued on 27 January $2015^{90}$-despite the ethical questions it poses and its legal peculiarities, given above all by attempts to alter civil status documents-presents various assonances with the principles established by the ECtHR in the first two decisions. The ECtHR referred to two elements: the good faith of the parents who commissioned the fact that the absence of the biological link was due to an error whose responsibility was not imputable to them and to the existence of a de facto family life that was established between the purchaser parents and the child and the consequent applicability of the art. $8 \mathrm{ECHR}$ in the present case, admitting the appeal. The six months spent the couple with the child were considered sufficient to create a family bond. On this basis, the ECtHR decided to consider the measures taken by the Italian authorities to be an illegitimate interference in private and family life. Just consider the case X and others v. Austria of 19 February 2013, in which the Court of Strasbourg condemned Austria for having denied a woman the right to adopt her partner's son, as a permit to heterosexual de facto couples. The ECtHR recognized that the couple had long lived together in a stable manner and that together they had taken care of the son of one of the two, so the relationship between the three could well be included in the

${ }^{87}$ Spano, R., The future of European Court of Human Rights-subsidiarity processbased review and the rule of law, en Human Rights Law Review 18 (2018), 3.

${ }^{88}$ Wagner and J.M.W.L. v. Luxembourg 28 June 2007; Negrepontis-Giannisis v. Greece of 3 May 2011. See in argument: CARPANETO, L., In-depth consideration of family life $v$. Immediate return of the child in abduction proceedings within the $E U$, en Rivista Diritto Internazionale Privato e Processuale (2014), pp. 932 ss.

${ }^{89}$ Fulchiron, H. - Bidaud-Garon, C., Reconnaissance ou reconstruction? A propos de la filiation des enfants nés par GPA, au landemain des arrêts Labassée, Mennesson et Campanelli-Paradiso de la Cour européenne des droits de l'homme, en Revue Critique de Droit International Privé 104 (2015), 1, pp. 4 ss.

${ }^{90}$ In the same spirit of orientation also the next cases: Laborie v. France of 16 January of 2017; Foulon v. France of 24 January 2014 and Bouvet v. France of 21 July 2016. O'Halloran, K., Adoption law and human rights: International perspectives (London \& New York, Routledge, 2018). 
notion of "family life". With a combined provision of art. 14 and 8 of the ECHR, the Court therefore recognized the right of the homosexual couple $^{91}$ to the adoption of the partner's child ${ }^{92}$, the so-called step-child adoption, where it is permitted for heterosexual de facto couples.

The Labassee and Mennesson judgments mark another crucial step in the evolution of the relationships between conventionally protected fundamental values and techniques for recognizing foreign sentences. In this case the ECtHR has subjected the choices made by the French judges to the application of the relative international-private system, on the basis of the rights, considered separately, to respect for private life and family life as per art. 8 of the European Convention of Human Rights $(\mathrm{ECHR})^{93}$. In doing so, the ECtHR defines pretoria rules ${ }^{94}$ that shape recognition techniques as a function of conventionally guaranteed values; in a logic that is typical of the relationship between international law and domestic law, which moves, in fact, from the priority of conventional standards to those of the forum. In limiting, to a considerable extent, the discretionary power of the State, the ECtHR proposes an original key to reading the margin of appreciation doctrine, an expression of the subsidiary nature of the conventional protection of human rights with respect to the internal one. The pronunciations tend to relativize the effectiveness of the international public order, making it emerge a very reduced application sphere so as to make the forum open to the entry of foreign normative values ${ }^{95}$.

The public order exception is compressed by two factors: the preeminence of the interests of the minor who is the most vulnerable subject, and the right of the same, considered essential, to personal identity. This jurisprudence shows that even in the absence of "consensus" among the contracting States (about the discipline of a certain phenomenon) the

${ }^{91}$ Bernard, A., Samenspender, Leihmütter, Retortenbabies: Neue Reproduktionstechnologien und die Ordnung der Familie, en Das Standesamt (2013), pp. 138 ss.

92 BORG-BARTHET, J., The principled imperative to recognise same-sex unions in the EU, en Journal of Private International Law 8 (2012), pp. 360 ss. Gallo, D., et al. (eds.), Same-sex couples before national, supranational and international jurisdictions (Berlin, Springer, 2014), pp. 458 ss.

${ }^{93}$ See, Rainey, R. - Wicks, E. - Ovey, C., Jacobs, White and Ovey: The European Convention on Human Rights (Oxford, Oxford University Press, 2017), pp. 375 ss.

${ }^{94}$ Liakopoulos, D., Interactions between European Court of Human Rights and private international law of European Union", en Cuadernos de Derecho Transnacional 10 (2010), pp. 252 ss.

${ }^{95}$ Bromfield, N. F. - Sмith Rotabi, K., Global surrogacy, exploitation, human rights and international private law: A pragmatic stance and policy recommendations, en Global Social Welfare 1 (2014), pp. 126 ss. 
margin of appreciation available to them does not allow-it is obvious that it is state conduct that collides with fundamental rights. Perhaps it is not so much a matter of shrinking the margin of appreciation as some passages of the ECtHR seem to mean, given that the level of protection of fundamental rights is built around common values conventionally imposed according to the interpretation given by the Court. More generally, one would say, it is the whole internationalist-nationalist structure of the forum that is affected, when it comes into contact with the protection of conventionally guaranteed rights: this is demonstrated by some passages of the ECtHR's reasoning and the results which, by interpretation, were received. French authorities derogating from the conflict system in order to give a fair response to sensitive, complex and considered interpersonal realities worthy of legal protection.

Without going into the details of the usual logical process followed in the judicial application of art. $8 \mathrm{ECHR}$, it should be noted that, from the perspective of ECtHR, the margin of appreciation reserved for the Contracting States ${ }^{96}$, depending on what is necessary in a democratic society, is compressed if the existence of the status of a minor is at stake, status which is (rightly) considered by the ECtHR an integral, essential part of its personal identity ${ }^{97}$. Consequently, the national authorities are called upon to identify a balance point which tends to place itself more on the side of the superior interests of the child and family life-deemed to be of primary importance ("paramount"; intended "à primer") that on the needs of protection of the state society and of the interests of the adult subjects involved in maternity surrogation events ${ }^{98}$.

${ }^{96}$ ARAI-TAKAHASHI, Y., The margin of appreciation doctrine and the principle of proportionality in the ECHR (Cambridge, Cambridge University Press, 2002). Lugato, M., The margin of appreciation and freedom of religion: between treaty interpretation and subsidiarity", en Journal of Catholic Legal Studies 52 (2013) , pp. 52 ss. LEGG, A., The margin of appreciation in international human rights law. Deference and proportionality (Oxford, Oxford University Press, 2012), pp. 62 ss. GERARDs, J., Margin of appreciation and incrementalism in the case law of the European Court of Human Rights, en Human Rights Law Review 18 (2018), 2.

${ }^{97}$ EctHR: Gaskin v. United Kingdom of 7 July 1989. This case law was developed further after this decision in a number of other judicial decisions, such as notably: Mikulić v. Croatia of 7 February 2002; Odièvre v. France of 13 February 2003; Jäggi v. Switzerland of 13 July 2006; Phinikaridou v. Cyprus of 20 December 2007; Godelli v. Italy of 25 September 2012. See in argument also: AchmAD, C., Children's rights to the fore in the European Court of Human Rights' first international commercial surrogacy judgments, in European Human Rights Law Review 6 (2014), pp. 640 ss.

${ }^{98}$ Medina, G., Jurisprudencia del Tribunal Europeo de Derechos Humanos en tema de reproducción, en Actualidad Juridica Iberoamericana 1 (2014), pp. 54 ss. 
The ECtHR followed a similar approach in the Paradiso and Campanelli judgment. This approach is not contradicted by the division of the legal analysis of the cases Labassee and Mennesson into two distinct profiles concerning, one, the respect for the right to family life of the individuals concerned (the biological father ${ }^{99}$, the mère d'intention et minor) and, the other, respect for the child's right to privacy. Formally justified by the duplicity of rights guaranteed by art. 8 , the logical path is also explainable due to the different conclusions reached, in fact, the ECtHR. However, for the reasons outlined below, these conclusions do not underlie a radically different level of protection between the right to family life and the right to a child's private life. If it is true that the latter is more pronounced than the first, the respect of the family status, considered as a whole, of the people involved in maternity events by subrogation, seems to move from a minimum standard, however, which took place in France. The conventional protection of the two rights appears, in short, less different than the reading of the respective dicta can induce prima facie to believe. This has happened-and the point deserves to be underlined, if we want to fully appreciate the impact of fundamental rights on the matter in question-by way of derogation from the functioning of international-private practices. In this perspective, the principles established in Labassee, Mennesson (and also in Paradiso and Campanelli) appear likely to extend to the functioning of other national conflict systems.

In conclusion, we can say that the room for maneuver that the denial of the existence of a family life guarantees to the ECtHR for future cases of surrogate motherhood would have been maintained, even if the Grand Chamber had ascertained the existence of a family life. Indeed, to the extent that the ECtHR had to declare the conformity of European conduct, rectius of all member countries to the $\mathrm{ECHR}^{100}$, it would have been better if the Grand Chamber had confirmed the substantial approach to defining family life and applied the doctrine of the margin

${ }^{99}$ Witzleb, N., Vater werden ist nicht schwer?', en Festschrift für Dieter Martiny (Tübingen, Mohr Siebeck, 2014), pp. 204 ss., against e.g. AG Friedberg, 1 March 2013, Az. 700 F 1142/12AG Zeitschrift für das gesamte Familienrecht 2013, p. 1994; AG Neuss, 14 May 2013, Az. 45 F 74/13, Zeitschrift für das gesamte Familienrecht 2014, pp. 1127. STURM, F., Dürfen Kinder ausländischer Leihmütter zu ihren genetischen Eltern nach Deutschland verbracht werden?, en Festschrift für Gunter Kühne (Frankfurt, Recht \& Wirtschaft, 2009), pp. 920 ss.

${ }^{100}$ Mulligan, A., Identity rights and sensitive ethical questions: The European Convention on Human Rights and the regulaton of surrogacy arrangements, en Medical Law Review 26 (2018), 3, pp. 452 ss. 
of state appreciation. Of course, the protection of the family unit would have been scratched. Nevertheless, the risk of a weakening of the factual notion of family life would have been avoided, while the application of the margin of appreciation doctrine, also with respect to the protection of the family unit, would have ensured greater certainty with regard to future appeals concerning surrogate motherhood. At the same time, the conferral of a decisive role to the margin of state appreciation, also with respect to the protection of the family nucleus, would not definitively circumscribe the screening of the Court in matters of surrogate maternity, given the known flexibility of the margin of appreciation: ECtHR would have in any case, the possibility of a jurisprudential change was maintained due to the evolution of the consensus common to the States parties of the ECHR.

\section{Protection And Respect of the Right to FAmily Life}

With regard to the individuals involved in surrogacy events, the ECtHR considered that the right balance between individual rights and the interests of the State was concretely achieved by the French authorities. It points out, for the purposes of this conclusion, the fact that the non-recognition of possession of the acquired state abroad has not precluded them from living together in France in the form, legally protected, of a family unit. Certainly, in Labassee and Mennesson the ECtHR rejects the claim of the applicants (parents d'intention) to obtain the transcription in France of the legal relationship established by the US jurisdictional measures. Such an outcome would have probably given rise to a condition of full family life: the child would have essentially taken the status of filius familias with respect to the recurring spouses. However, on closer inspection, the judgment, favorable to the French Government, stems from a clear factual premise that helps to explain the outcome: a minimum level of family life protection was guaranteed in this case, given that the French authorities, regardless the denied transcription of the state certificates in the civil status records had linked to these certifications a series of legally relevant consequences (the possibility of obtaining French citizenship so as to exclude the risk that minors are expelled from the French territory, social recognition ${ }^{101}$, for parents of

${ }^{101}$ See from the EctHR the case: Pontes v. Portugal of 12 April 2012, in which the ECtHR: “(...) necessity in the meaning of Article 8 paragraph 2, to mean "a pressing social need" that needs to be in proportion to the legitimate aim that is pursued. Regardless of breaching national and international legislation, residing with the applicants' would not have constituted a situation where aforementioned 
intention, parental responsibility, the legal protection of minors in case of divorce of the spouses because they are considered members of the family unit, and, finally, the enjoyment of rights of succession in favor of minors). The foreign certificate was therefore deemed suitable to produce such legal effects in itself in France, despite the refusal to recognize the filii status with regard to the applicants. The impression is that if the French authorities had not prepared such pro-tectives and if, therefore, they had deconstructed the minimal core of the right to family life, preventing the intentional parents and minors from sharing a unified family dimension, the judgment on the point it would have been different. The ECtHR, in fact, seems to appreciate the sensitivity shown by the French authorities towards situations of family life, socially and emotionally, complex and delicate. Judges and local administrative authorities have made use of interpretative techniques and application practices to ensure, in a surreptitious manner, an intangible core of protection even in the face of the non-recognition of the American declarations of the existence and validity of the filiation relationship. Surreptitious, precisely because they arrive at a result, legally relevant in the French legal system, which appears to be inconsistent with the general functioning of the internationalprivate mechanisms of the forum as applied by the same authorities who should have carried out strictly not to give any legal effect (not even surrogacy) to such sentences. Be that as it may, since membership in family society is the essential core of the corresponding condition.

\section{RESPECT FOR THE CHILD’S RIGHT TO PRIVACY}

The ECtHR then considered that France violated the child's right to private life for having judged that the American judgments were incompatible with ordre public international: in fact, the birth certificates of the children concerned, initially noted in France in accordance with these sentences had been canceled. The accent is placed, in Labassee and Mennesson, on the primary need of the minor to be recognized as the filii status with respect to the parental figure of the biological father. The possession of this state, conceived as a fundamental right of the person, of his identity and individuality ${ }^{102}$, seems to be the central element of

qualifications for 'necessity' would have fulfilled (...) removing the child from the applicants' care who had been assessed and approved for adoption without so much as a consult from an expert was not proportionate considering the interests at stake (...)".

${ }^{102}$ According to Van Bueren: "(...) an identity transforms the biological entity into a legal being and confirms the existence of a specific legal personality capably of 
the European Court's reasoning, while the observations on the legal uncertainty situation of the minor and on the difficulties inherent in enjoyment both of French citizenship and of successors rights, appear to be complementary in the argumentative process. It is significant in this regard the passage in which the ECtHR, even after highlighting these uncertainties and difficulties, insists that the acquisition of the status wire towards the biological father is a primary element of the child's personal identity: having been precluded of "établir la subs-tance de son identité, y compris sa filiation", his right to private life is "significantment affecte" 103 .

Although in a different factual framework, the Paradiso and Campanelli judgment also aims to reduce the scope of the limit of the international public order that can not represent the ECtHR-carte blanche suitable to justify, in the face of the obligations imposed by art. 8 , any measure against a minor, disregarding the concrete consideration of his superior interest. The removal of the child from the host family is, according to the ECtHR, the extrema ratio to which the authorities of the State can resort to the sole purpose of protecting the child from immediate danger. In assessing the primary interest of the child, according to the ECtHR, “(...) est estcecare qu'un enfant ne soit désavantagé du fait qu'il a été mis au monde par une mère porteuse, à commencer par la citoyen-neté ou l'identité qui revêtent un primordial importance (...)"104.

\section{INABILITY TO RECOGNIZE INDIRECTLY THE EFFECTS PRODUCED BY GESTATIONS FOR SUBSTITUTION: WILL AND LOST FILIATION?}

It seems to represent a first and indirect step towards the recognition of the possibility of creating bonds of filiation through simple will. This, however, does not seem sufficient in itself to create a bond of filiation among strangers. All this, not because you introduce an element (the will to create a child) that is not relevant even in natural filiation (in which regardless of whether the child is wanted or not, once conceived is of those who conceived it) but rather because, so reasoning, through an act of mere will it is attributed to a third party (the minor who, however,

bearing rights and duties (...)". VAN BUEREN, G., The international law on the rights of the child (Leiden, The Martinus Nijhoff, 2006), p. 117. KILTY, M., The right to know the identities of genetic parents, en Australian Journal of Adoption 7 (2013), 2, pp. 5ss.

${ }^{103}$ Boele-Woelki, K. - Dethlof, N. - Gephart, W., Family law and culture in Europe: Developments, challenges and opportunities (Antwerp, Oxford, Intersentia, 2014), pp. 202 ss.

${ }^{104}$ Henrich, D., Leichmüt-terkinder: Wessen Kinder?, en Praxis des Internationalen Privat-und Verfahrensrechts 35 (2015), pp. 232 ss. 
passively undergoes the effects of that decision) a status that is made not only of coercible obligations (material assistance), but also of incoercible obligations (moral assistance). The situation would present itself, in some ways, in a very similar way to what happens in marriage. In this circumstance, it is true that international treaty law derives from the mere will the establishment of personal relationships made not only of coercible claims but it is equally true that, when the will to maintain those relations is not granted, the parties are granted possibility of dissolving that bond. This is quite reasonable in light of the fact that it seems illusory to convince oneself that a subject may be obliged to love, respect, assist and take care of a foreign human being, even if that relationship has been constituted with an expression of will that, at the moment of its manifestation, it was fully and wholly genuine. But parentage is something profoundly different. What is not taken into account is the fact that even in these cases the will-for the most disparate events-could change over time and allow the danger to the emergence of a dissociation between genetic data and social data to emerge. To attribute to the willof-itself always volatile-the possibility of creating such constraints seems to create difficulties in the full realization of the interest of the child that add up to those that already normally characterize the relationships between parents and children ${ }^{105}$.

And in fact, if by a manifestation of will of this kind - which must necessarily be irrevocable-the order can easily lead to the obligation for parents to fulfill their duties of material assistance towards a person who has juridically become their son, how will he be able to oblige them-after they have "repented" the manifestation of willpower-to properly fulfill their moral duties towards the child? How will he guarantee that they will continue to be good parents towards a child who, if at first they wanted to be their own child, now do not consider him as such (because this, in fact, is not)? And if during the gestation changes the will of the surrogate mother who, eventually, has also provided her genetic material for the creation of the embryo? Who is the mother? Would it be legitimate to take the child away from the parturient or, on the contrary, would this activity also qualify as an illegitimate intrusion into the private life of the child? It does not seem that this can be objected to by the fact that not even the biological constraint ensures the parents' ability to take care

${ }^{105}$ Blyth, E. - Crawshaw, M. - VAn DEN AKKer, O., What are the Best interests of the child in international surrogacy?, en Bionews 742 (2014). KeYES, M. - CHISHOLM, R., Commercial surrogacy: Some troubling family law issues, en Australian Journal of Family Law 27 (2013), pp. 105-134. Donnelly, J., Universal human rights in theory and practice ( ${ }^{\text {rd }}$ ed., Cornell, Cornell Press, 2013). 
of their children since this aspect, certainly possible, can only confer a pathological and marginal position in the way normally they develop parental relationships so much so that, where the above hypothesis occurs, surely the order reacts by activating a procedure for adopting the child in a state of abandonment ${ }^{106}$. At the same time, however, neglecting the power of the genetic bond in terms of closeness, and emotional transport to the vicissitudes of the other, is tantamount to neglecting a fact that nature itself imposes. Similarly, it does not seem fitting to compare a surrogate motherhood to an adoption procedure because the substantial difference-in addition to the function performed-lies in the control exercised on the couple who wants to gain access to its concrete ability to perform correctly its parental function towards a child with whom it has no genetic bond. This control does not exist in the case of surrogate motherhood in which everything is remitted to a self-judgment-at least partial and, therefore, not entirely reliable-of suitability of the client couple to play their role as parents for the entire life of a human being which is not genetically traceable to them. But what happens next is not always progress and therefore it is up to the jurist's sensibility to use correct filters in order not to be dazzled by the blinding light of interests that are certainly of primary importance but which, if poorly managed, do not allow discerning contours of what surrounds us. To state that it is not correct to subtract from a couple a minor with whom he has no connection-except for the on $\mathrm{e}^{107}$ in favor of a woman to have a baby generated then brought into in the country of reception from requesting parents unless the same couple behaves in such a way as to pose in serious and present danger the psycho-physical integrity of the minor, it is in fact equivalent to legitimizing the surrogate motherhood carried out abroad because, in fact, we are going to recognize the right to retain the child so created with the client couple. But the interest of a minor who does not have any traceable bond of blood in the world-unless he wants to condemn to "one hundred years of solitude"-is not realized through temporary and unstable permanence at the "highest bidder" "with which,

106 Laufer-Ukeles, P., Mothering for money: Regulating Commercial intimacy, surrogacy, adoption, en Indiana Law Journal 88 (2013), pp. 1280 ss.

${ }^{107}$ STARK, B., Transnational surrogacy and international human rights law, en Ilsa Journal of International \& Comparative Law 18 (2011-2012), pp. 382 ss. PAVONE, L. R., Medically assisted procreation and international human rights law, en Italian Yearbook of International Law 23 (2013), pp. 160 ss. DAmelio, J. - Sorensen, K., Enhancing autonomy in paid surrogacy, en Bioethics 8 (2008), 2, pp. 270 ss. BRUGGER, K., International law in the gestational surrogacy debate, en Fordham International Law Journal 34 (2011-2012), pp. 672 ss. 
perhaps, begins to establish links that will then be severed. It seems, on the contrary, that the effective protection of the child, if you want to give it "a second opportunity on earth", is to be entrusted to a couple who, after having undergone the examination of the legal system, has been judged by the company civil and democratic in which we still live, suitable to take care of that subject in a stable and definitive manner.

International law, both public and private, as well as the law of the European Union has imposed in practice the obligation to respect the fundamental rights of individuals in the terms in which they are defined by sources and jurisdictions outside the forum means that the application techniques of international private family law should be shaped around common principles of human rights protection. Consequently, there is a double process of approximation of the reference values of the national laws and of the respective family models. The activity (or activism) of the ECtHR shows, in particular, that neither the endogenous perspective that aims to absorb the protection of human rights in the national Constitution concerning the discipline of the cases that present elements of extraneousness, and even less that international methodologicalnationalistic, are enough keys to explain the evolution in progress ${ }^{108}$. Nor are they always appropriate-not always-to resolve the orderly conflicts between their respective reference values when the overall ordering of the forum is built around principles of constitutional rank that prevent coordination with foreign jurisdictions, if they are inspired by values irreconcilable with them. In this case, it is the international obligation of the State that tends to impose exceptions to the system of conflict of the forum and, ultimately, to its primary reference values. It would be simplistic to argue that these derogations only concern the limit of the international public order since-to limit ourselves to the cases considered above-the French practice shows the relevance of birth certificates drawn up abroad for subsidiaries not recognized by virtue of the conflict system.

In this perspective, the international and community jurisprudence, together with the national one, on maternity by subrogation is projected along the unitary thread of protection of the rights of the child, that is, of the most vulnerable figure among those involved. The consequent protective logic, however, extends ratione personarum beyond the minor, accepting, albeit at a lower level of protection, the adults, one of whom is often also the biological parent-intent on taking parental tasks. In this way, a legal form, legitimated by rules of international origin, is set up for

${ }^{108}$ Gruenbaum, D., Foreign surrogate motherhood: Mater semper certa erat, en American Journal of Comparative Law 60 (2012), pp. 475 ss. 
personal relationships born abroad in violation of the normative values of the forum.

It could of course be noted that this perspective, focusing on the figure of the minor, is partial and therefore open to criticism. In fact, in such complex situations- in which legal evaluation intersects with highly debated ethical issues-it marginalizes the fundamental rights of other people. Consider, for example, the provisions aimed at repressing the trafficking of human beings, if it is accepted that the surrogacy of motherhood, on the one hand, interferes with the dignity of the pregnant woman and affects the rights of the infant that is assimilated to an object it is arranged by contract (of sale) or other instruments of negotiating autonomy; and on the other hand, it is likely to give rise, at least in certain cases, to subtle forms of slavery. However, such arguments are destined to take on a de iure condendo weight, with a view to abolishing procreation on behalf of others through a broadly universal or multilateral universal agreement ${ }^{109}$. This is probably the only viable way if you wanted to counteract the root "(...) the practice of gestational surrogacy which involves reproductive exploitation and use of the human body for financial or other gain (...)" 110 . In so doing, the international order would obviously be in a prohibitionist (even pedagogical) perspective.

Instead, looking for systemic solutions in the current regulatory framework implies an operation of choice between fundamental values and rights in friction between them and not reducible through balancing of norms and values. In the absence of normative solutions and in the face of a factual reality to be settled by way of interpretation, it is not unreasonable to argue that the point of equilibrium is to be found in

${ }^{109}$ Report on the Annual Report on Human Rights and Democracy in the World 2014 and the Eu-ropean Union's policy on the matter (2015/2229(INI)), par. 114: The Euuropean Parliament: “(...) condemns the practice of surrogacy, which undermines the human dignity of the woman since her body And its reproductive functions are used as a commodity; considers that the practice of gestational surrogacy which involves reproductive exploitation and use of the human body for financial or other gain, in particular in the case of vulnerable women in developing countries, shall be prohibited and treated as a matter of urgency in human rights instruments (...)". HALE, B., Regulation of international surrogacy arrangements: do we regulate the market, or fix the real problems?, en Suffolk Transnational Law Review 36 (2013), pp. 502 ss.

${ }^{110}$ Tobin, T., To prohibit or permit: What is the (human) rights response to the practice of international commercial surrogacy, en International and Comparative Law Quarterly 63 (2014), pp. 318 ss. VETTOREL, A., International surrogacy arrangements: Recent developments and ongoing problems, en Rivista di Diritto Internazionale Privato e Processuale (2015), pp. 528 ss. 
the protection of the child whose legal status, regardless of legislative prohibitions and ethical considerations, it can not be penalized because of individual choices supported by a medical science that seems to exert a dominant, in many ways debatable, on procreation. As already outlined elsewhere, if one remains on the level of the search for realistic legal solutions, the priority of the minor's rights, uti singulus, constitutes the point de repère because of the intrinsic position of vulnerability in which he is placed by procreation for account of others. In the chaos of the evolution of family relationships, the child first approach has its own raison d'etre in strict legal terms since it revolves around the principle of the primacy of the minor's interests in the procedures that concern him. It is a subjective right, contained in a conventional instrument with almost universal participation, self-executing and therefore directly invokable and applicable in court. Rebus sic stantibus, the protection of the rights of the child can be viewed on two levels ${ }^{111}$. Firstly, the continuity of the filii status acquired abroad with respect to the figure of the biological parent must be guaranteed if he is known and intends to responsibly perform the parental function in a conceptual scheme that basically aims at imitating natural parentage ${ }^{112}$. As the ECtHR jurisprudence seems to suggest, the acknowledged priority to biological truth leads one to think that the biological parent must be integrated into the full condition of the parent. On the other hand, if one considers that he is nothing more than an additional figure compared to the traditional father ${ }^{113}$

${ }^{111}$ General Assembly Official Records Sixty-ninth session, Supplement No. 41 (A/69/41), Report of the Committee on the Rights of the Child, United Nations, New York, 2014, p.1.

112 Committee on the Rights of the Children, General comment No. 14 (2013) on the right of the child to have his or her best interests taken as a primary consideration (art. 3, para. 1), United Nations CRC/C/GC/14, 29 May 2013, p. 4. BRacken, L., Assessing the best interests of the child in cases of cross-border surrogacy: in consistency in the Strasbourg approach?, en Journal of Social Welfare and Family Law 39 (2017), 3, pp. 372 ss.

113 According to the author: ERGAS, Y., Bodies without borders: humna rights, buman dignity and the regulation of international commercial surrogacy, en Emory International Law Review 27 (2013), pp. 122 ss. It might be objected that the widespread strictures against women's marital infidelity were designed to ensure that "sanguinis" actually denoted the physical link between the father and the child. Indeed, under the Justininan Code, once a woman notified her husband that she was pregnant, he could either "send guards or (...) give notice to her that she is not pregnant by him (...) unless he sends guards or replies giving her notice she is not pregnant by him, the husband is compelled to acknowledge the offspring (...) but this objection fails to take into account the near-impossibility of either children born outside of marriage or men who had fathered children to women 
identified by the marital relationship with the pregnant woman (where it exists, according to the maximum pater est quem nuptiae demonstrant), one should imagine the creation of a special legal status of parent from surrogate motherhood (biological parent) destined to coexist with the first. In this case there would be a problem of adaptation (Angleichung) of difficult solution in the legal systems that are inspired by traditional conceptions of the family: devolve it to jurisprudence would seem to demandate to it a task that exceeds its role ${ }^{114}$.

In any case, the possession of the relevant subjective legal status by the minor is considered a primary element of the personal identity of the minor: if he was not allowed to enjoy this essential right, his right to privacy would be jeopardized. And besides, the child's right to know his origins should also include biological ones, achieving their relative status. In this perspective, the relationship of filiation should also affirm itself towards the genetic mother with respect to the woman who led the pregnancy and renounced parental rights. There is, however, a right to parenting in favor of the adult who is not able to procreate naturally due to the infertility of others or the spouse or partner. This right is recognized and protected, but it is set up as secondary only if its exercise takes place only when the pre-eminent rights of the child (primary law, as it were) are achieved. The right of the minor, understood as an individual, uti singulus, to the recognition of the filii status has priority over the secondary right to parenting for the following considerations.

The appreciation of the interest of the child presupposes a casebased evaluation, having to take into account all the circumstances of

married to other men to bring paternity suits well into the twentieth century. See Michael H. v. Gerald D., 491 U.S. 110 (1989) (denying a filiation action filed by a man who sought to prove his paternity of a child born out of wedlock because of a rebuttable presumption that that a child of born to a married woman is the child of the husband of that woman). A recent German lower court reiterated the primacy of legal relations with respect to the establishment of Paternity at least where surrogacy is involved, even though jus sanguinis rules would normally apply (...) The court sustained the German Embassy's right to deny nationality to children born of a German father (who would normally be entitled to transmit his citizenship to his offspring) and an Indian gestational carrier (...) the court held that under German law "the legal father of a child born to a surrogate is considered to be the surrogate mother's husband not the biological father (...) in this case the biological father's German citizenship was legally irrelevant (...)”.

114 STARK, B., Transnational surrogacy and international human rights law, en ILSA Journal of International and Comparative Law 18 (2012), pp. 372 ss. ERGAS, Y., Babies without borders: Human rights, human dignity, and the regulation of international commercial surrogacy, en Emory International Law Review 27 (2013), pp. 118 ss. 
the specific case. Faced with the situation of a biological parent, even if married, who resorts to surrogate motherhood for selfish purposes (for example because of old age), it is doubtful whether it is in the interest of the child to recognize the status acquired abroad.

On a different level, and although the affirmation of the fundamental right to the continuity of state ownership often lends itself to assume a preeminent character in situations of aspiration to parenthood dictated by altruistic motivation, the issue of recognizing the status in question to homosexual persons could be delicate. in the systems that absolutely preclude access to parenting, including the adoptive one. In this regard, a precise jurisprudential orientation has not yet been formed (from ECtHR, in particular) and the issue, in the context of filiation, will need to be assessed in terms of equal social dignity and the prohibition of non-discrimination (especially of women) ${ }^{115}$ and on the basis of sexual orientation $^{116}$.

Secondly, as we have seen, in relations with the child there is a tendency to recognize even the spouse (or partner) without biological links a minimum sphere of legal protection. These relationships are recomposed in the State of recognition becoming partially "claudicant" compared to the State of origin. However, the former is not obliged to give that person the status of parent (legal parent). In fact, in the State of accueil a minimum level of family life must be guaranteed not only in the relationships between the child and the biological parent, but also in relation to the adult person who has promoted the surrogate procreation in agreement with the former. We pass here from the rights of the minor, meaning uti singulus, to the rights of persons other than the child connected to him in a family relationship. There emerges a notion of family life worthy of protection because it is based on the observation of an effective and consolidated personal link between the individuals concerned, and in particular on the voluntary assumption of parental responsibility towards a minor; with the consequences of the case in terms of acceptance of the legal and moral, affective, educational and material rules, which preside over the exercise of the parental function. The

115 Convention on the Elimination of all Forms of Discrimination Against Women, G.A. Res 34/180, art. 11.2, 12, 14, 16 U.N. GAOR, Supp. No. 46, U.N. Doc. A/34/46, at 193 (Sept. 3, 1981) (CEDAW). See: STARK, B., Transnational surrogacy and international human rights law, en ILSA Journal of International \& Comparative Law 18 (2012), pp. 372 ss.

${ }^{116}$ See from the EctHR the case: X and others v. Austria of 19 February 2013. BALA, N., The hidden costs of the European Court of Human Rights' surrogacy decision, en Yale Journal of International 11 (2014), pp. 16 ss. 
asymmetry between the order of origin and the state of recognition could be filled, from the point of view of the second order, through legislative reform, by drawing a special parental figure or using the institution of adoption.

On a more general level, the effectiveness in the forum of personal status acquired abroad ultimately determines a phenomenon of movement of family models within the territorial scope of the ECHR; and this is true within the narrower geographical area of the European Union by virtue of the principle of mutual recognition of personal and family legal situations; it would be difficult to imagine, for example, that a subsidiary recognized in France could have no legal effect in other Member States of the Union where the family unit moved by using the rules on the free movement of persons. It follows that, taken as a whole, national systems may also assume apparently inconsistent outlines: they retain a power of regulation on the internal level (by virtue of the doctrine of the margin of appreciation) and can prohibit (even criminal) procreation on behalf of others; at the same time, however, they are not in a position to oppose the recognition of status acquired abroad in favor of foreigners or their own citizens when this result leads to violations of the rights of the child. The birth (and therefore the existence) of the minor is configured as a legally relevant fact that requires the adoption of a priority protective perspective addressed to the weaker subject.

It can not be ruled out that, at the end of the day, the more restrictive regulations are progressively carried out-by effect of what we have defined as a process of approximation of the reference values-to share more open principles regarding filiation. It would be desirable, however, that such a process of value osmosis would be produced through the prism of an international multilateral treaty, around negotiated rules, also to define many profiles that deserve shared insights: consider, for example, the limits of age for access to motherhood by subrogation, to controls so that this form of procreation is aware and free, and to those to fight abuse, exploitation of the condition of poverty. Consider still the discipline of aspects still uncertain in many legal systems (inheritance type, attribution of nationality to the child, the solution of the controversy between a plurality of adults who claim parental functions on the same minor, creating special parenting conditions where opt for the acceptance of multi-country relations, etc. $)^{117}$. In this perspective, international law

${ }^{117}$ Hague Conference on Private International Law, A Preliminary Report on the Issues Arising from International Surrogacy, pp. 25 ss. Trimmings - Beaumont, cit. (n. 16), pp. 628 ss. 
would opt for the acceptance of the pluralism of familiar forms, far beyond the traditional ones. However, it could also happen that a totally prohibitionist approach to motherhood prevails at a multilateral level by means of subrogation, considering that denial of parenting is prevalent and therefore the right of the child not to be born in this condition. Precisely for the reasons mentioned above, for these purposes the most effective instrument would be the adoption of an internationally agreed instrument.

Finally, it should be emphasized that, whatever the normative evolution (totally permissive approach or regulated access to motherhood through subrogation or its absolute prohibition), the national systems that regulate conflicts of laws must progressively adapt to prevailing normative values regarding human rights. Consider, for example, the observed tendency to reduce the sphere of application of the limit of the international public order as an exception to the recognition in the forum of legal situations established abroad. It is confirmed, on a general level, what has already been noted in previous writings, namely that the discipline of private international law is not neutral in terms of normative values, as instead once the doctrine believed on the basis of its alleged instrumental nature, because intended to ensure only the right distribution of normative and jurisdictional power between sovereign states. The formalistic and abstract reasoning that has characterized in the past the debate on international-private justice (international privatrechtliche Gerechtigkeit), of a merely distributive justice, must be rejected on the ground that in principle law, can not be, above all on the issue of family, bearer of axiologically neutral choices. It is evident then that the interference on the Italian system of conflicts of laws will have to be measured taking into account the condition of inter-state rules reserved by the Constitutional Court to the provisions of the ECHR. On the one hand, the obligation of a consistent interpretation of the rules of conflict (as ordinary sources) to the ECHR (which is placed at a higher level than ordinary law because of its interposed nature) could reassemble the whole in a unitary design; in any case it would be a very difficult result to achieve considering the intrinsic limit (given essentially by the absolute irreconcilability of the reference values of our system of private international law with the jurisprudential principles of ECtHR) which presides over the technique of conforming interpretation. On the other hand, that line of jurisprudence does not exclude a check of constitutionality of the same Council on normative values guaranteed by the ECHR: the Constitutional Court could, in hypothesis, react to the entrance of external values irreconcilable with the fundamental principles 
of the forum, thus determining a breaking point with conventional obligations ${ }^{118}$.

On the other hand, if the national system on conflicts of laws is aligned, through its own legislative reforms or originating from international or Union instruments, to the international evolution in terms of recognition of statuses acquired abroad in situations of surrogacy, one would have another demonstration that the state power to dictate the discipline of cases that present elements of extraneousness is less and less declining in terms of exclusive sovereignty. In fact, national systems of private international family law undergo continuous processes of transformation due to the influence of sources external to the forum that impose, on the one hand, a test of compatibility with fundamental rights (rights to private and family life) ${ }^{119}$ and, on the other hand, positive obligations to recognize family status. There is a relationship of direct proportionality between exceptions to the functioning of the internal rules on conflicts of laws-through the techniques of recognition of legal situations constituted validly abroad or recognized therein-and the impact of external sources on the structural principles of national conflict systems.

\section{Conclusions and Proposals}

The interpretative process that we have followed allows us to think that many values, principles, and so on both at the international, community and national levels can be countered-and often are by specialist doctrinefears of contamination and, ultimately, of fragmentation of national conflict systems. In reality, private international law and that of the family in particular, are not ontologically different from any other field of domestic law that undergoes the inevitable transformations due to the opening to international and European normative values and social developments that, whether they like it or not, they are determined. Rather than a fragmentation of private international law, it would therefore be appropriate to reflect in terms of the natural evolution and 2014.

118 See from the ECtHR the next case: Cataldo and others v. Italy of 24 June

${ }^{119}$ DAVIS, E., The rise of gestational surrogacy and the pressing need for international regulation, en Minnesota Journal of International Law 21 (2012), pp. 120 ss. BAKER, H., A possible future instrument on international surrogacy arrangements: Are there "lessons" to be learnt from the 1993 Hague Intercountry Adoption Convention?, en International surrogacy arrangements: Legal regulation at the international level (Portland \& Oregon, Oxford, Hart Publishing, 2013), pp. 412 ss. EnGEL, cit. (n. 57). 
approximation of the legal systems considered as a whole. The juridical relativism that private international law assumed as an almost indefectible presupposition of its work appears to be increasingly subjected to progressive erosion ${ }^{120}$.

According to our opinion a new Hague Convention or EU legislation: must ensure the suitability of the intending parents in order to protect the best interests of the child and must also preserve the intending parents' rights and interests; should make a clear determination of legal parentage at the outset, even before the birth of the child, to preserve the child's best interests and legal rights; regardless of what happens during the pregnancy, the child is not left stateless once it is born; must ensure the suitability of the surrogate mother and preserve her welfare and autonomy in the process; should facilitate an efficient method to collect accurate information about the various parties to the agreement.

As a consequence, the European Union can only regulate this area if it manages to prove subsidiarity, which means that there is a crossborder dimension which requires action on EU-level. Furthermore, the principle of proportionality must be met and the action must not violate the Member States' competences. There are various competences which would allow the EU to take action in this field, if the described principles are met. There are first of all the fundamental rights, which according to Article 6.2. TEU must be respected by the EU. The main fundamental right to be respected in connection with the framing of surrogacy is the protection of children, regulated in Art 24 of the charter of fundamental rights and Art 3 TEU.But there are also other competences that could allow a positive action, namely the freedom of movement of patients (Art 56, 34, 114 and $168 \mathrm{TFEU}$ ), the freedom of movement of cells (Art 114 and $168 \mathrm{TFEU}$ ), the freedom of movement of citizens and European citizenship (Art. 20 and 21 TFEU), non-discrimination (Art 19 TFEU), and European international private law (Art. 67 (4) and 81 TFEU).

Courts should enforce the contract in a surrogacy arrangement ${ }^{121}$.

${ }^{120}$ De Toledo, L. A., El futuro de la maternidad subrogada en España: entre el fraude de Ley y el correctivo de orden público internacional, en Cuadernos de Derecho Transnacional 6 (2014), 2, pp. 8 ss.

121 In the case C-336/94, Eftalia Dafeki v. Landesversicherungsanstalt Württemberg of 2 December 1997, (ECLI:EU:C:1887:579, ECR, I-06761) the CJEU ruled that the institutions and the courts of a Member State must accept certificates and documents concerning the personal status issued by the competent authorities of another Member State. In two other cases, however, namely in case: C-391/09, Runevic-Vardyn of 12 May 2011 (ECLI:EU:C:2011:291, ECR I-03787) and case C-208/09, Ilonky Sayn-Wittgenstein v. Landeshauptmann von Wien of 22 
The debate of whether surrogacy contracts should be permitted should not factor into the court's decision with regards to the enforceability of such contracts. Persons objecting to surrogacy should register their complaints with the legislatures. To successfully prove conversion, the intended mother would have to show the following: $a$ ) a property interest in the child; $b$ ) a right to immediately possess the child; $c$ ) the surrogate is wrongly keeping the child; d) has made a demand for possession of the child. A modernisation of these instruments in the light of societal, technological and legal developments in the member States would provide an opportunity to remedy some gaps in the existing EU legal framework on reconciliation issues. It is submitted that a more comprehensive EU approach to leaves, working time adjustments and care facilities should include more rights to be able to take caring responsibilities, not only for mothers and fathers but also for other relatives. The issue of care should therefore be more prominent on EU's social agenda and in global level than up to now.

December 2010, (ECLI:EC:2010:806, ECR I-13693) the CJEU ruled: “(...) that States can limit the recognition in the light of their sovereignty, when it comes to constitutional traditions. Taking these rulings into consideration it is easy to imagine that public policy arguments could also be used by the CJEU in a case concerning the civil status of a child born out of an international surrogacy agreement. 